IZA DP No. 10330

Detailed Geographic Information, Conflict Exposure, and Health Impacts

Richard Akresh

German Daniel Caruso

Harsha Thirumurthy

October 2016 


\title{
Detailed Geographic Information, Conflict Exposure, and Health Impacts
}

\author{
Richard Akresh \\ University of Illinois at Urbana-Champaign, \\ NBER, BREAD and IZA \\ German Daniel Caruso \\ The World Bank \\ Harsha Thirumurthy \\ University of North Carolina at Chapel Hill \\ and BREAD
}

\section{Discussion Paper No. 10330 \\ October 2016}

\author{
IZA \\ P.O. Box 7240 \\ 53072 Bonn \\ Germany \\ Phone: +49-228-3894-0 \\ Fax: +49-228-3894-180 \\ E-mail: iza@iza.org
}

Any opinions expressed here are those of the author(s) and not those of IZA. Research published in this series may include views on policy, but the institute itself takes no institutional policy positions. The IZA research network is committed to the IZA Guiding Principles of Research Integrity.

The Institute for the Study of Labor (IZA) in Bonn is a local and virtual international research center and a place of communication between science, politics and business. IZA is an independent nonprofit organization supported by Deutsche Post Foundation. The center is associated with the University of Bonn and offers a stimulating research environment through its international network, workshops and conferences, data service, project support, research visits and doctoral program. IZA engages in (i) original and internationally competitive research in all fields of labor economics, (ii) development of policy concepts, and (iii) dissemination of research results and concepts to the interested public.

IZA Discussion Papers often represent preliminary work and are circulated to encourage discussion. Citation of such a paper should account for its provisional character. A revised version may be available directly from the author. 


\title{
ABSTRACT
}

\section{Detailed Geographic Information, Conflict Exposure, and Health Impacts*}

\begin{abstract}
We estimate the impact of exposure to conflict on health outcomes using geographic information on households' distance from conflict sites - a more accurate measure of shock exposure - and compare the impact on children exposed in utero versus after birth. The identification strategy relies on exogenous variation in the conflict's geographic extent and timing. Conflict-exposed children have lower height-for-age, and impacts using GPS information are 2-3 times larger than if exposure is measured at the imprecise regional level. Results are robust to addressing endogenous migration. Health service disruptions and maternal stressors are potential explanations for the negative health effects on children.
\end{abstract}

JEL Classification: $\quad 112, \mathrm{~J} 13, \mathrm{O} 12$

Keywords: child health, conflict, fetal origins hypothesis, Africa

Corresponding author:

Richard Akresh

University of Illinois at Urbana-Champaign

Department of Economics

1407 W. Gregory Drive

David Kinley Hall, Room 214

Urbana, IL 61801

USA

E-mail: akresh@illinois.edu

\footnotetext{
* We thank Leonardo Lucchetti, Daniel McMillen, Muhammad Nasir, Elizabeth Powers, and seminar participants at the Households in Conflict Network conference, Midwest International Economic Development Conference, and Pacific Development conference for helpful comments on earlier drafts. We also thank Leonardo Lucchetti and Rafael Garduno-Rivera for help in generating the ArcGIS map in Figure 1. This paper was previously circulated as "Medium Term Health Impacts of Shocks Experienced In Utero and After Birth: Evidence from Detailed Geographic Information on War Exposure."
} 


\section{Introduction}

Environmental and economic shocks experienced in utero and early childhood have been shown to be especially harmful not only because they affect health outcomes in the short-term but also because they influence health and economic outcomes in adulthood (see reviews by Strauss and Thomas, 2008; Currie and Vogl, 2013). ${ }^{1}$ The possibility that early-life growth disturbances can affect future health outcomes is particularly relevant in sub-Saharan Africa, where armed conflict has occurred with greater frequency than in other regions of the world. Nearly 70 percent of all countries in that region have experienced an armed conflict since 1980 (Raleigh et al., 2010). Despite the destruction and deaths caused by conflicts and the potential for such shocks to affect various indicators of well-being, the impacts of exposure to conflict on child health have only recently started to receive attention in the literature. ${ }^{2}$ One significant challenge in measuring this impact is the lack of detailed geographic information on household residence in most nationally representative surveys, which makes it more difficult to identify children who are exposed to early life shocks.

This paper studies the effects of the 1998-2000 Eritrea-Ethiopia conflict on the subsequent health status of children by using survey data from both

\footnotetext{
${ }^{1}$ Research exploring the impact of shocks has focused on different adverse events including malnutrition (Case et al., 2005; Maluccio et al., 2009; Maccini and Yang, 2009; Almond and Mazumder, 2011), famine (Dercon and Porter, 2014), conflict (Bundervoet et al., 2009; Akresh et al., 2011; Akresh et al., 2012; Mansour and Rees, 2012; Akbulut-Yuksel, 2014; Valente, 2015; Akresh, 2016), diseases and epidemics (Almond, 2006; Bleakley, 2007; Bhalotra and Venkataramani, 2012), natural disasters and extreme weather events (Currie and Rossin-Slater, 2013; Aguero, 2014; Caruso, 2014a, 2014b; Rosales-Rueda, 2014), and pollution (Currie et al., 2009; Nilsson, 2009).

${ }^{2}$ Early research on conflict focuses on understanding the causes of war and its growth-reducing role (Collier and Hoeffler, 1998; Miguel et al., 2004; Do and Iyer, 2010; Harari and La Ferrara, 2013; Burke et al., 2015). The size of the long-term economic consequences of conflicts is debated in the literature (see Davis and Weinstein (2002) for Japan; Brakman et al. (2004) for Germany; Bellows and Miguel (2009) for Sierra Leone). Research also examines the relationship between conflict exposure and education (Akresh and de Walque, 2008; Miguel and Roland, 2011; Shemyakina, 2011; Swee, 2015). Research that focuses only on soldiers finds negative impacts on their earnings, and soldiers who experience more violence have a more difficult time reintegrating into civilian society (Angrist, 1990; Blattman and Annan, 2010).
} 
countries that contain information on the geographic location of households and also by taking advantage of variation in the timing of the conflict with respect to when children were born. By utilizing geographic location data, the paper identifies the effect of exposure to conflicts more accurately than prior studies. Most other research on in utero and early childhood exposure to shocks generally focuses on variation at a broader regional level to capture shock exposure (Almond, Currie, and Herrmann, 2012; Adhvaryu, Bharadwaj, Fenske, Nyshadham, and Stanley, 2016; Adhvaryu, Fenske, and Nyshadham, 2016; Shah and Steinberg, forthcoming). Moreover, this paper compares the health effects of in utero versus early childhood exposure to the conflict, thereby assessing the relative importance of growth disturbances during these two critical periods. Lastly, the paper explores several plausible mechanisms by which the conflict may have affected child health, focusing in particular on the role of disruptions in health care delivery and maternal stressors.

The 1998-2000 Eritrea-Ethiopia conflict was based on a land border dispute between the two countries. Eritrea, which was formerly a province of Ethiopia, became independent in 1993 following a long guerrilla conflict, but sections of the new border were never officially demarcated. Full-scale fighting began in May 1998 over these disputed areas, which have been described as desolate and inconsequential. Hundreds of thousands of troops were dug in and deadlocked on both sides of the border. Most of the conflict's casualties were soldiers, as civilians left the conflict areas, leaving the armies to fight over empty villages. The availability of Demographic and Health Survey (DHS) data collected in both countries in the years following the conflict (Eritrea in 2002; Ethiopia in 2000 and 2005) provides a unique opportunity to study the effects of this conflict on subsequent health outcomes of children. The primary outcome that we study is a child's height-for-age Z-score, an important measure that captures lingering effects of any growth disturbances that may have occurred earlier in life. 
This paper makes two main contributions to the literature on the impacts of shocks on children's welfare and significantly extends previous research on this topic. First, to identify the impact of conflict-related shocks, the paper addresses the traditional difficulty in correctly classifying a child's exposure. Whereas a typical approach is to compare potentially large regions that did and did not experience the shock, in this paper we use global positioning system (GPS) data on the distance between survey villages and conflict sites to more accurately measure the likely exposure that a child had to the conflict. In previous research, in particular (Akresh et al., 2012), exposure measures used were less precise and the focus was on outcomes in only one country (Eritrea). Using the more detailed GPS data corrects the potential misclassification of a child's shock exposure. For example, in Eritrea, 24\% of households within 100 kilometers $(\mathrm{km})$ of conflict sites had been previously coded as being in non-conflict regions, while in Ethiopia, 28\% of households within 100-300 km of conflict sites had been previously coded as being in non-conflict regions and $2.2 \%$ of households that were more than $300 \mathrm{~km}$ from the conflict sites were coded as being in a conflict region. We show that using the GPS data makes a difference in the estimated effects of conflict, with households living closer to conflict sites having 87-188\% larger impacts than if less precise regional measures of exposure are used. ${ }^{3}$

\footnotetext{
${ }^{3}$ The contributions highlighted here are also the key differences between this paper and the most closely related prior work by Akresh et al. (2012) who explore the impact of this same war on health outcomes but only for Eritrean children. In particular, being able to accurately locate a child's household due to GPS data ensures that we correctly measure the child's war exposure and address the shortcomings in previous research. While that previous research found that correcting for a household's war-time migration across regions led to estimated negative impacts that are $13 \%$ larger, we find that taking into account how far the household is from the conflict sites leads to negative impacts of conflict exposure that approximately double in magnitude in Eritrea and triple in Ethiopia. Due to data limitations, it is not possible to correct for both the war-time migration across regions and the GPS distance to the conflict, but it is clear that the GPS correction is substantially larger. In addition, the current paper measures the welfare impacts for both sides involved in a conflict, thereby providing a more comprehensive and robust understanding of how winning or losing such conflicts affects children's well-being.
} 
A second contribution of this paper follows from the fortuitous timing of when household surveys were implemented in Eritrea and Ethiopia, which enables us to explore whether effects of the conflict differ between children who were in utero during the conflict and those who were in early childhood. There are a number of reasons why in utero exposure may be harmful to child health. These include poorer maternal nutrition due to disruptions in food supply or income shocks, a lack of adequate antenatal care, and the possibility that the conflict reduced the number of baby deliveries in the presence of trained providers. Our paper examines the relative importance of exposure during these two critical time periods, something that has not been done in previous research on the effects of armed conflicts. Contrary to recent papers that report no later-life effects of shocks experienced in utero (Endara et al., 2009; Maccini and Yang, 2009; Fletcher, 2014), a notable result in our paper is that Ethiopian and Eritrean children exposed to the conflict in utero do have significantly lower heights.

Results indicate there was a significant reduction in the height-for-age Zscores of children who resided in conflict-affected regions during the conflict. This effect increased with the number of months of conflict exposure; in Eritrea, each month of exposure (in utero and after birth) resulted in a significant reduction in the Z-score of 0.039 standard deviations, while in Ethiopia the reduction was 0.017 standard deviations. Based on the average number of months that children in the DHS samples were exposed to the conflict, these estimates translate into overall reductions of 0.73 and 0.26 standard deviations, respectively. Classifying conflict exposure based on GPS distance from conflict sites reveals that children nearest to conflict sites suffered even larger effects (1.37 and 0.76 standard deviations in Eritrea and Ethiopia, respectively), and the negative impact diminished as distance from the conflict increased. These results highlight the importance of measuring exposure to shocks with detailed geographic information rather than region-based indicators. Lastly, results indicate that the magnitude of 
the negative height effects during both critical periods (in utero and after birth) is similar in size. Despite the specific context of the Ethiopia-Eritrea conflict, the results offer important insights on the effects of conflicts, which continue to occur in Africa and other regions.

The remainder of the paper is organized as follows. Section 2 provides an overview of the history of the Eritrea-Ethiopia conflict and sketches the spatial and temporal event data for the 1998-2000 conflict. Section 3 describes the survey data used in the analysis and explains the key variables. Section 4 describes the empirical identification strategy and Section 5 presents the main results as well as robustness tests. Section 6 concludes.

\section{Background on the Eritrean-Ethiopian Conflict}

The Eritrean-Ethiopian conflict lasted two years and began due to a border dispute. Additional background details about the conflict are provided in Human Rights Watch (2003) and Akresh et al. (2012). In brief, much of the fighting that occurred during the conflict was in the three border areas of Badme, TsoronaZalambessa, and Bure (see Figure 1 for a regional map of Eritrea and Ethiopia highlighting these areas). Both countries claimed sovereignty over these areas. The conflict officially began in May 1998 in the Badme area, which was then under Ethiopian control, and both countries subsequently spent substantial funds to grow their armies, augment their military equipment, and fortify their borders. Periods of intense fighting continued over the next two years. A Cessation of Hostilities agreement was brokered on June 18, 2000 and a 25-kilometer-wide demilitarized Temporary Security Zone was established along the 1,000 kilometer Eritrea-Ethiopia border and patrolled by United Nations peacekeeping forces. A final comprehensive peace agreement was signed December 12, $2000{ }^{4}$

\footnotetext{
${ }^{4}$ For the analysis in this paper, we treat this as the date the war ended, but results are consistent if we use June 2000, the date when the Cessation of Hostilities agreement was signed, as the time when the war ended.
} 
The exact timing and location of the violence plays a key role in our empirical strategy for identifying the effects of the conflict on child health. Specifically, an important determinant of conflict intensity was the distance from the conflict sites, which were the three village locations (Badme, TsoronaZalambessa, and Bure) along the border between Eritrea and Ethiopia. Locations far from these three border areas experienced little or no fighting; the most intense violence took place in those border areas. While exact figures of the number of casualties due to the conflict are difficult to ascertain, most estimates of the total number of fatalities, mainly among soldiers, range from 70,000-100,000 (Human Rights Watch, 2003).

Even though most casualties were soldiers, thousands of civilians were displaced and this represented a central mechanism through which conflict may have affected child health. Displaced households suffered large reductions in food production, asset losses, and had limited access to clean water or health infrastructure. By late 1998, estimates suggest approximately 250,000 Eritreans had been internally displaced and another 45,000 Ethiopian citizens of Eritrean origin were deported from Ethiopia (Global IDP Project, 2004a). The Eritrean government and other observers estimate that during the conflict nearly 1.1 million Eritreans were internally displaced, although this number declined substantially by the conflict's end (Global IDP Project, 2004a). The Ethiopian government estimates that by December 1998, 315,000 Ethiopians were internally displaced, with the two regions that border Eritrea (Tigray and Afar) having the greatest number of internally displaced persons (IDPs). The United Nations Ethiopia Country Team estimates that by May 2000 the number of IDPs in Ethiopia had risen to 360,000 (Global IDP Project, 2004b). ${ }^{5}$ By most accounts,

\footnotetext{
${ }^{5}$ This level of conflict-induced displacement is typical, as currently 27.1 million individuals worldwide are IDPs due to conflict. For example, during the last decade in Africa, the number of IDPs due to conflict reached 3.5 million in Angola, 633,000 in Burundi, 200,000 in Central
} 
households directly affected by the conflict and those that were internally displaced tended to be originally located closest to the areas of the clashes.

\section{Data}

3.1 Demographic and Health Surveys: Eritrea (2002), Ethiopia (2000 and 2005) Our analyses make use of three waves of data from the DHS conducted in Eritrea and Ethiopia. The DHS are nationally representative cross-sectional surveys that gather information on demographic topics such as fertility, child mortality, health service utilization, and nutritional status of mothers and young children. The 2002 Eritrea DHS collected detailed information on the date of birth, GPS location, and height of 5,139 children under five born before, during, or after the conflict with Ethiopia. The 2000 Ethiopia DHS collected similar information for 9,619 children under five, all of whom were born before or during the Eritrea conflict. To have a control group of children in the conflict regions of Ethiopia who were not exposed to conflict, we also use the 2005 Ethiopia DHS that has information for 4,217 children under five. Our analyses rely on DHS data for information on health outcomes (described below) as well as other individual and household characteristics of children including geographical information on their residence at the time of the survey and in some cases during the time of the conflict.

\subsection{Health Outcomes}

Since child height (conditional on age and gender) can be sensitive to past growth failures due to malnutrition or illness, it is generally accepted as a good way to capture long-term health disturbances (World Health Organization, 1995). Using anthropometric information contained in the DHS for children 0-60 months of age, we compute Z-scores for each child's height-for-age, where the Z-score is

African Republic, 180,000 in Chad, 150,000 in Congo-Brazzaville, 750,000 in Côte d'Ivoire, 3 million in Democratic Republic of Congo, 359,000 in Guinea, 600,000 in Kenya, 450,000 in Liberia, 550,000 in Nigeria, 600,000 in Rwanda, 70,000 in Senegal, 1.3 million in Sierra Leone, 1.5 million in Somalia, 6.1 million in Sudan, 1.7 million in Uganda, and 1 million in Zimbabwe (IDMC, 2010). 
defined as the difference between the child's height and the mean height of the same-aged international reference population, divided by the standard deviation of the reference population. Our analysis also examines other information on health behaviors and health outcomes to better understand mechanisms by which conflict may influence height-for-age Z-scores. In particular, we examine data on hospital deliveries, alcohol and bed net usage during pregnancy, self-reported birth size, and maternal postpartum amenorrhea.

\subsection{Measures of Conflict Exposure}

We construct three measures of a child's exposure to the Eritrea-Ethiopia conflict. The first is defined at the region-birth cohort level and is a continuous measure of the number of months of conflict exposure. This allows us to exploit variation across two dimensions: spatial (variation across regions in exposure to the conflict) and temporal (within a given region, the timing of whether a child was in utero or early childhood during the conflict period). Specifically, we use information on a child's region of residence and date of birth to calculate the number of months the child was exposed to the conflict in utero (defined as 9 months prior to the date of birth) and the number of months a child was exposed to the conflict after birth. The exposure measure is set to zero months if the child resided in a region that was not affected by the conflict. As we discussed in Section 2, the fighting was centered on the border areas near the three towns of Badme, Tsorona-Zalambessa, and Bure, so in Eritrea, the conflict regions are defined as Gash Barka, Debub, and Debubawi Keyih Bahri, while in Ethiopia they are Tigray and Afar.

Since conflict-induced displacement was an important mechanism through which the conflict impacted child health, we also incorporate direct measures of the number of IDPs in each region to proxy for the conflict's intensity. The IDP data come from the United Nations Office for the Coordination of Humanitarian Affairs (UN OCHA) in Eritrea and Ethiopia. All of the IDPs are clustered in the 
three conflict regions in Eritrea and the two conflict regions in Ethiopia (Global IDP Project 2004a, b). Specifically, we use the number of IDPs in each region divided by the region's pre-war population as a measure of conflict intensity.

Lastly and most importantly, to address potential measurement error that would wrongly misclassify children as conflict-exposed simply because they live in a region that experienced fighting (regardless of the proximity of their village to conflict sites) or as non-conflict exposed simply because they live in a nonconflict region (even if their village is near to conflict sites), we construct a third measure of conflict exposure using GPS information on the child's residence location at the time of the survey and the number of months of exposure for each child. We first calculate a continuous measure of proximity to conflict sites using the distance from each survey village to the nearest conflict site. ${ }^{6}$ We also then classify exposure based on different distance bands of less than 100 kilometers (km), 100-200 km, 200-300 km, and greater than $300 \mathrm{~km}$. In creating these proximity measures, we use distance to the nearest conflict site even if it crosses region boundaries. The distance measure (either the continuous one or the bands) is then interacted with the number of months of exposure to create the third conflict exposure measure.

\section{Empirical Identification Strategy}

Our approach to determining the impact of the conflict on child health relies on an examination of how height-for-age Z-scores of children vary as a function of different durations of exposure to the conflict and variation in the degree to which their area of residence was affected by the conflict. We begin by estimating the following regression that includes region and birth cohort fixed effects:

\footnotetext{
${ }^{6}$ Specifically, proximity is defined as the maximum distance in that country from a conflict site minus the household's actual distance to the nearest conflict site divided by 100 . Note that in the data, the survey household that is closest to a conflict site is 17 kilometers away. To be clear, in these survey villages there was no fighting that took place, but the conflict measure is capturing proximity to conflict battles that occurred in the border areas between Ethiopia and Eritrea.
} 
(1) $H A Z_{i j t}=\alpha_{j}+\delta_{t}+\beta_{1}$ Total Months War Exposure ${ }_{i j t}+\beta_{2} X_{i j t}+\gamma_{j t}+\varepsilon_{i j t}$ where $H A Z_{i j t}$ is the height-for-age Z-score for child $i$ in region $j$ who was born in period $t, \alpha_{j}$ are region fixed effects, $\delta_{t}$ are year of birth cohort fixed effects, Total Months of War Exposure ${ }_{i j t}$ measures the total number of months a child was alive or in utero during the conflict period and living in a conflict region (it equals zero for children in regions unaffected by the conflict), and $\varepsilon_{i j t}$ is a random, idiosyncratic error term. The regression also includes household and individual level controls $\left(X_{i j t}\right)$, such as child gender and household head schooling. In addition, to address the potential for differential time trends in height-for-age Zscores across regions, the regressions include region-specific time trends $\left(\gamma_{j t}\right)$. The coefficient $\beta_{1}$ measures the effect of an additional month of exposure to the conflict on children's height-for-age Z-scores. It is important to emphasize that identification of the effect of the conflict in this model comes from variation in the duration of exposure (conditional on adjustments for age cohort effects) rather than a simple comparison of conflict and non-conflict regions.

Building on Equation (1), we estimate the following regression to gauge if the conflict impact differs by whether a child was exposed in utero or after birth:

$$
\begin{aligned}
& H A Z_{i j t}=\alpha_{j}+\delta_{t}+\beta_{1} \text { Months War Exposure In Utero }_{i j t} \\
& +\beta_{2} \text { Months War Exposure After Birth }{ }_{i j t}+\beta_{3} X_{i j t}+\gamma_{j t}+\varepsilon_{i j t}
\end{aligned}
$$

where Months War Exposure In Utero ${ }_{i j t}$ measures the number of months a child was in utero during the war period and living in a conflict region and Months War Exposure After Birth ${ }_{i j t}$ measures the number of months a child was alive during the war and living in a conflict region.

Residence in a conflict region alone does not capture the size of the disruptions caused by the conflict. To address this, we consider an alternative definition of conflict exposure that measures the number of IDPs in each region as a proportion of the region's pre-war population. As war-induced displacement 
was likely an important channel through which conflict impacted child health, this measure will proxy for the conflict's intensity in that region. The conflict intensity variable is interacted with total months of war exposure described above. Identification comes from variation across regions with different numbers of IDPs as well as variation in the duration of exposure to the conflict. We estimate the following regression incorporating IDP data:

$$
\begin{gathered}
H A Z_{i j t}=\alpha_{j}+\delta_{t}+\beta_{1} \text { Intensity of Total Months War Exposure }_{i j t} \\
+\beta_{3} X_{i j t}+\gamma_{j t}+\varepsilon_{i j t}
\end{gathered}
$$

We also estimate modified versions of Equation (3) in which the conflict effect varies based on the number of months of exposure in utero and after birth.

In defining conflict exposure based on living in one of the three regions in Eritrea or two regions in Ethiopia where fighting took place - or even on the basis of the number of IDPs in each region - there is a potential for incorrect classification of villages as being conflict-exposed. This can result in biased estimates as some regions extend many kilometers from conflict sites (see Afar in Ethiopia and Debubawi Keyih Bahri in Eritrea). To more accurately measure a child's conflict exposure, our empirical strategy takes advantage of information on the distance of each survey village to the conflict sites. We test for the effect of each additional month of exposure to the conflict with a continuous measure of proximity to conflict sites and with three different distance categories (with a fourth category of greater than $300 \mathrm{~km}$ serving as the reference group):

(4) $H A Z_{i j t}=\alpha_{j}+\delta_{t}+\beta_{1}$ Total Months War Exposure by Proximity ${ }_{i j t}$

$$
+\beta_{2} X_{i j}+\gamma_{j t}+\varepsilon_{i j t}
$$

(5) $H A Z_{i j t}=\alpha_{j}+\delta_{t}+\beta_{1}(\text { Total Months War Exposure } 0-100 \mathrm{~km})_{i j t}$

$$
\begin{gathered}
+\beta_{2}(\text { Total Months War Exposure } 100-200 \mathrm{~km})_{i j t} \\
+\beta_{3}(\text { Total Months War Exposure } 200-300 \mathrm{~km})_{i j t} \\
+\beta_{4} X_{i j t}+\gamma_{j t}+\varepsilon_{i j t}
\end{gathered}
$$


where Total Months War Exposure by Proximity measures the number of months a child was alive or in utero during the war period by proximity from conflict sites, Total Months War Exposure 0-100 km measures the number of months a child was alive or in utero during the war period and living within 0-100km from conflict sites, with the other exposure variables defined similarly but for different distances from conflict sites.

Our empirical analyses also include several extensions to the regressions above as well as robustness checks. Importantly, since the main regression results are based on a child's residence at the time of the survey, there is a possibility of bias due to children having resided elsewhere during the time period of the conflict. We take two approaches to address this issue. First, all children from households that reported having lived during the conflict in a different location than their current village are reclassified as having resided in a conflict region during the conflict. ${ }^{7}$ This is a conservative approach to dealing with the bias due to endogenous migration as some of these households who moved during the conflict and currently reside in a non-conflict region might have been living in another non-conflict region during the war. Second, for Eritrea, but not Ethiopia, we can use information in the survey on the region of residence at the time of the conflict to examine what happens to the results when this reclassification is done.

\section{Empirical Results}

\subsection{Difference-in-Differences Estimation (War Region and Geospatial Location)}

Table 1 provides summary statistics for children who live close $(0-100 \mathrm{~km})$ or farther away (greater than $100 \mathrm{~km}$ ) to conflict sites. In both countries, children living close to conflict sites have lower Z-scores than those residing farther away,

\footnotetext{
${ }^{7}$ This involves reclassifying $10.9 \%$ and 5.9\% of children in Eritrea and Ethiopia, respectively. In Eritrea (but not Ethiopia), we also have data on the region of residence at the time of the conflict, and we can tell that only $3.9 \%$ of children should have been reclassified instead of $10.9 \%$. Information on the duration of continuous residence was obtained by asking each household the number of years they continuously lived in the village where they were living at the time of the survey.
} 
although the difference is statistically significant only in Ethiopia. Children near conflict sites are also worse off in other ways, as indicated by lower schooling attainment of household heads and higher percentages living in rural areas.

In Table 2, we present the results assessing the impact of the conflict focusing on the region-based measure of conflict exposure. Specifically, we present results from estimating Equations (1) and (2) for Ethiopia (panel A) and Eritrea (panel B). ${ }^{8}$ In the first two columns, a child's residence is classified according to the region of residence at the time of the survey. In columns 3 and 4 , a child's residence is classified according to the assumption that any child who moved during the conflict resided in a conflict region at the time of the conflict. In columns 5 and 6, using data available for Eritrea only, a child's residence is classified as their known region of residence at the time of the conflict to accurately capture conflict exposure. Column 1 of Table 2 shows that for children exposed to the conflict in utero or after birth, each additional month of exposure results in a significant reduction of height-for-age Z-scores (by 0.017 in Ethiopia and 0.039 in Eritrea). To interpret these results more easily, we consider the magnitude of the effect for children exposed to the conflict for the average duration in each country: in Ethiopia, exposure yields an overall reduction of 0.23 standard deviations in their height-for-age Z-score, while in Eritrea, exposure leads to an overall reduction of 0.73 standard deviations.

\footnotetext{
${ }^{8}$ In all of the regressions, we include child age fixed effects, region fixed effects, region-specific time trends, DHS round fixed effects (for Ethiopia), child gender, and the following household characteristics: household head's gender, age, years of schooling, mother's height, number of members in the household, number of children in the household under age 5, and whether the household resides in an urban area. Correlation among the error terms of children living in the same local environment and experiencing similar health shocks might bias the OLS standard errors downward, so in all regressions we cluster the standard errors by enumeration area, which corresponds to local clusters of villages (Moulton, 1986). Using pre-war poverty data for all regions in Eritrea and Ethiopia, we also confirm that the results in the paper are similar when nonwar regions are limited to those with similar pre-war poverty levels as the war regions.
} 
When children's exposure is classified on the basis of their assumed residence at the time of the conflict (column 3), the effects on height-for-age Zscores remain similar (-0.014 in Ethiopia and -0.040 in Eritrea) and continue to be statistically significant. This indicates our results are robust to an extremely conservative adjustment for migration during the conflict. In Eritrea, the results based on classifying residence as the region in which the child resided at the time of the conflict (column 5) also shows a similar effect size to that obtained when residence is classified as the region of residence at the time of the survey.

Another important result in Table 2 pertains to the distinct effect of exposure to the conflict in utero as opposed to early childhood. In both Ethiopia and Eritrea, we find that the effects of exposure after birth are larger (reductions in the Z-scores of 0.019 and 0.047 for each month of exposure in Ethiopia and Eritrea, respectively), although we cannot reject equality in Eritrea. In Ethiopia, there is no statistically significant effect on height-for-age Z-scores of in utero exposure to conflict. In contrast, in Eritrea, in utero exposure does result in a significant reduction of Z-scores by 0.034 for each month of exposure. In summary, Table 2 (measuring exposure at the region level) provides evidence that exposure to the conflict after birth in the conflict regions is associated with significant negative effects on height-for-age $\mathrm{Z}$ scores.

Using an alternative measure of conflict exposure - the intensity of the conflict in the child's region of residence - Table 3 presents results that are largely consistent with those reported in Table 2 . It is in the regions most affected by the conflict that children experience the largest setbacks to their growth. Each month of exposure reduces the height-for-age Z-scores of children, and this impact increases as a function of conflict intensity in the region. The main results, based on residence at the time of the survey, indicate that an increase of 1 percent in the IDP proportion of a region's population reduces the height-for-age Z-scores by 0.0017 and 0.0015 for each month of total exposure (in utero and after birth) in 
Ethiopia and Eritrea, respectively. ${ }^{9}$ The effects remain negative and statistically significant when residence is based on classifying all children who migrated as having been in conflict regions. When the effects of the conflict are allowed to differ as a function of exposure in utero and after birth (column 2), we find statistically significant effects of exposure after birth in both countries. ${ }^{10}$

Using geospatial data on the proximity of each household to conflict sites enables a more accurate estimation of whether conflict affects children's health. Table 4 presents results from estimating regressions that use the continuous proximity distance measure (Equation 4). We find that living in closer proximity to the conflict sites and experiencing an additional month of exposure in utero or after birth significantly reduce a child's height-for-age Z-score by 0.004 in Ethiopia and by 0.015 in Eritrea (Table 4, Panel A, columns $1 \&$ 2). Since the mean proximity index among children residing less than $100 \mathrm{~km}$ from conflict sites is 9.98 in Ethiopia and 3.19 in Eritrea, each additional month of exposure for a child with the average proximity index living within $100 \mathrm{~km}$ of the conflict sites reduces Z-scores by 0.040 and 0.048 in Ethiopia and Eritrea, respectively, and if these children were exposed for the mean conflict duration, they would suffer overall reductions of 0.619 and 0.901 standard deviations in Ethiopia and Eritrea, respectively. Panel A in Table 4 shows exposure and proximity to conflict sites is negatively related to child outcomes. These results underscore the importance of

\footnotetext{
${ }^{9}$ These impacts are large and meaningful, especially when considering the number of IDPs in each country. In Ethiopia and Eritrea, respectively, $8.6 \%$ and $21.1 \%$ of the population in the conflict regions were IDPs. In Ethiopia, the mean number of months of exposure for children in the survey sample was 15.5; in Eritrea it was 18.8. Thus, a child who experienced the conflict for the mean number of months in a region experiencing the average war intensity would have 0.23 or 0.60 standard deviations lower height-for-age Z-scores in Ethiopia and Eritrea, respectively.

${ }^{10}$ It is possible that households experiencing negative shocks sent out children to live with other relatives (see Akresh (2009) for evidence on the link between negative shocks and child fostering). Although we do not have any information in the survey about this, we are unable to tell which direction, if any, this might bias the results depending on whether the healthiest or the least healthy child was fostered, but most of the literature on child fostering finds the rate of fostering for children under five to be extremely low.
} 
geographical data for illuminating the effects of conflict and accurately measuring the size of these effects. ${ }^{11}$

In Panel B in Table 4, we separately examine the effect of exposure in utero and after birth and results indicate that in the areas closer to conflict sites, both types of exposure result in negative impacts on height-for-age Z-scores. This is true in both Ethiopia and Eritrea. Effects of in utero and after birth exposure are roughly comparable in magnitude. While the estimates for Ethiopia indicate smaller negative impacts in utero compared to after birth, we cannot reject equality of the coefficients with a p-value of 0.32 . However, in Eritrea, impacts in utero are statistically larger than those after birth.

While the evidence suggests large and significant reductions in height-forage Z-scores as a result of conflict exposure, an important public policy and intrahousehold resource allocation question is whether boys and girls are affected differently. With this in mind, the results in Table 5 are noteworthy because they show remarkably similar negative impacts of conflict exposure in both countries for boys as well as girls. The magnitude of the impact is slightly larger for boys but in neither country are the differences statistically significant. ${ }^{12}$

As part of the analyses, we also pooled the Ethiopia and Eritrea data to directly compare the effects of the conflict in the two countries. Specifically, we

\footnotetext{
${ }^{11}$ It is important to note that the migration data in the DHS surveys is only at the region level. Therefore, to estimate the regressions in columns 3 and 4 based on potential residence at the time of the war, we make the extremely strong assumption that any child who moved during the war was actually living at a conflict site and so is assigned a distance to the conflict site of zero kilometers. This implies that the proximity measure will attain its largest possible value for these children. In Ethiopia and Eritrea, respectively, 18 and 15 percent of the children in the sample were re-assigned a distance to the conflict site of zero kilometers for columns 3 and 4 . Results using potential residence show a smaller negative impact of conflict exposure, although the coefficients remain statistically significant in both countries.

${ }^{12}$ Our results differ from much of the literature that usually finds a gender bias as a result of exposure in early childhood to other type of shocks besides armed conflict (see Alderman and Gertler, 1997; Duflo, 2003; Jayachandran, 2009; Maccini and Yang, 2009; and Rose, 1999). This difference with the literature highlights that the potential mechanisms may differ depending on the type of adverse shock.
} 
estimate a fully interacted model, including interactions of an indicator variable for Eritrea with all other variables. Appendix Table 1 uses the region-based measure of conflict exposure, and results indicate conflict-exposed children in Eritrea have significantly lower height-for-age Z-scores than conflict-exposed children in Ethiopia (in column 1, there is an additional reduction of 0.023 for each additional month of conflict exposure in Eritrea). This result holds when we classify residency based on potential residency during the conflict (column 3). When we examine the separate effects of exposure in utero versus after birth (column 2), we find that children in Eritrea are more affected by the conflict. They have significantly lower height-for-age Z-scores as a result of in utero exposure (0.043 lower for each additional month of conflict exposure) and early childhood exposure (0.028 lower for each additional month of conflict exposure).

A similar pattern with the pooled data exists when we examine conflict impacts using the proximity to conflict sites measure. Appendix Table 2 Panel A shows that when taking into account proximity to conflict sites, children in Eritrea suffer larger negative effects on height-for-age Z-scores than children in Ethiopia. If we classify residency based on residence at the time of the survey (column 1), the effect of each additional month of conflict exposure for children living closer to conflict sites in Eritrea is 0.012 larger than in Ethiopia. ${ }^{13}$

\subsection{Robustness Checks}

To determine whether the conflict effects are robust to a range of possibilities that could bias results, in Appendix Tables 3-6 we present results from additional analyses. In Appendix Table 3, we use the proximity to conflict sites measure and include mother fixed effects, which allows us to control for characteristics of the child's mother that do not vary across siblings. In the sample of households with

\footnotetext{
${ }^{13}$ In Panel B in Appendix Table 2 using pooled data, we highlight the different impacts for children exposed in utero and after birth. Children who live closer to conflict sites and are exposed in utero or after birth experience larger negative impacts on height-for-age Z-scores in Eritrea than Ethiopia.
} 
multiple children less than 5 years of age, there are still significant negative effects for each month of conflict exposure in both Ethiopia and Eritrea, and the negative impact is larger for children living closer to the conflict sites.

In Appendix Table 4a and 4b, we define households' proximity to conflict sites on the basis of the absolute distance rather than relative distance within the sample. The results indicate that exposure at any distance within $300 \mathrm{~km}$ of conflict sites (relative to the reference group of children living more than $300 \mathrm{~km}$ from conflict sites) is negatively related to child outcomes. Importantly, results also show that within $300 \mathrm{~km}$ of conflict sites there is a decreasing gradient in the effect of conflict as a function of distance from conflict sites, with those children living within 0-100 km of the conflict sites experiencing larger negative impacts of conflict exposure.

Another concern regarding the validity of the main estimates relates to the possibility that fertility and mortality patterns may be different in areas that were exposed to the conflict with varying severity. We examine fertility patterns by comparing characteristics of women based on their region of residence and whether they had children during the conflict (Appendix Table 5). We find little evidence that women who had a child during the conflict and reside in a war region are systematically different than other women. In Ethiopia, there is evidence that women in conflict regions who had a child born during the conflict were taller (an effect that would likely bias our main results downward). In Eritrea, there is evidence of an effect on the age of women who had children, but this effect is likely too minor to influence the main results.

In Appendix Table 6, we use DHS data on under-5 child mortality to examine whether conflict exposure resulted in increased mortality. Even if there is a relationship between conflict and child mortality, then since the deceased children were likely those with poorer health (and possibly from poorer households), the main results reported in the paper would like be underestimated. 
We find no significant relationship between conflict exposure and child mortality. This lack of relationship should be interpreted in the context of a setting with already extremely high under-5 mortality (pre-conflict under-5 mortality rates in Ethiopia and Eritrea are 162 and 105 deaths per 1000 live births, respectively). ${ }^{14}$

\subsection{Conflict Impact Mechanisms}

Identifying specific reasons for the negative effects of conflict on child health can be useful for interpreting the main results and also developing policies to mitigate such negative effects in the future. While displacement of households might be a key channel through which children's health status is affected, the absence of detailed survey information on the displacement of specific households limits our ability to examine this issue thoroughly. Households close to conflict sites could have been directly worse off through loss of harvests and assets, disruption of own businesses, and reduced access to medicines, health clinics, and clean water. Those farther from the conflict sites, while experiencing smaller negative impacts on child health, could have been indirectly affected through changes in economic situations, market prices, employment, or cross-region trade. ${ }^{15}$ While the DHS data lack detailed information on many of these issues, in Table 6, we have the data to assess the impacts of the conflict on health services delivery, relevant health-seeking behaviors, and maternal stressors, all of which could be important mechanisms that explain how conflict exposure leads to negative health impacts.

First, access to health services could have been reduced during the conflict. We examine the conflict's effect on the likelihood children are delivered at a health clinic or hospital where the risk of infections is lower and availability

\footnotetext{
${ }^{14}$ An additional factor that could bias our results is also worth discussing briefly. Mismeasurement of a child's age would likely make our estimates lower bounds of the true impact, as parents would probably underreport the age of short children making their malnutrition seem less severe than it is. Since the household roster collects the exact birth date of all children under five in a household and misreporting on one child would be more difficult as it would influence the birth dates of the household's other children, such mismeasurement may be somewhat less likely.

${ }^{15}$ There could also be effects on children who were not displaced by the conflict but resided in areas with many displaced individuals (Baez, 2011).
} 
of personnel capable of managing complications is higher. Results (column 1) indicate that in Ethiopia the conflict had a negative impact on the likelihood of such delivery taking place. In Eritrea, impacts are not statistically significant.

Second, mothers could have changed their health behaviors in response to conflict exposure. Results (in columns 2 and 3) indicate that a child's conflict exposure is correlated with more alcohol drinking by the mother during pregnancy (in both countries) and in Eritrea, a reduction in child bed net usage, which would likely mean higher child malaria rates. There is no effect of conflict exposure on bed net usage in Ethiopia, but the baseline usage rate is quite low.

Third, prenatal maternal factors (including nutrition and stress) could have been affected by the conflict and led to reduced child birth weight. Mothers were asked during the survey about the size of their child at birth, and we examine (column 4) whether the child was reported to be "very small.” In Ethiopia, children in households close to conflict sites are more likely to have been "very small” at birth. In Eritrea, the impact on birth size is not statistically significant, which could be due to 'culling' of weaker fetuses during pregnancy (Valente, 2015). Additional evidence that mothers exposed to the conflict might have had worse nutrition or suffered more stress can be seen in column 5, which shows that conflict exposure led to greater durations of postpartum amenorrhea; the impacts are found in Eritrea and Ethiopia. Overall, disruptions in health services delivery (reductions in deliveries at clinics) combined with worse health-seeking behaviors (increased alcohol consumption during pregnancy and reduced child malaria prevention) and greater maternal stressors (longer durations of amenorrhea and increased low birth weight children) are potential mechanisms that could explain the negative health effects observed for conflict-exposed children.

\section{Conclusion}

This paper quantifies the medium-term health consequences of the EritreaEthiopia conflict using multiple conflict exposure measures. The findings show 
large negative effects on the height-for-age Z-scores of children exposed to the conflict. Since children and households in a number of other resource-limited settings, particularly in Africa, have been exposed to conflicts that feature internal displacement and disruptions of health services, this paper has relevance for the larger literature on the medium- and long-term effects of armed conflicts.

The empirical methods used in this paper overcome several challenges to identifying the causal effect of conflict exposure. We classify children's conflict exposure on the basis of the geographical coordinates of their residence. We also compare children exposed to the conflict for varying durations and at different stages (in utero and after birth). We find the effects of in utero and after birth exposure to the conflict are similar in magnitude, and children in the losing country (Eritrea) suffer more than the winning country (Ethiopia). Focusing on the estimates of children's conflict exposure based on GPS distance from conflict sites indicates that the Eritrea-Ethiopia conflict led to overall reductions of 0.76 to 1.37 standard deviations (approximately 1 to 2 inches) in Ethiopia and Eritrea, respectively, and the impact was less substantial as distance from conflict sites increased. These effect sizes of conflict exposure defined in terms of distance from conflict sites are approximately two- and three times larger (for Eritrea and Ethiopia, respectively) than the effect sizes of conflict exposure defined on the basis of politically demarcated subnational units, which is the standard approach taken in much of the research that examines the impacts of exposure to shocks. Future research focusing on exposure to conflict, as well as other types of earlylife disturbances, can work to better incorporate currently available GPS data that can be linked to individual survey data to determine how much exposure misclassification affects the magnitudes of the effect sizes (Bruck et al, 2013).

As height-for-age Z-scores are important health indicators of children and are associated with health and employment outcomes later in life, the results in this paper offer insight on the likely long-term effects of conflicts. Using available 
estimates of the effect of early childhood height on school attainment and wages, the results in this paper suggest that the conflict may lead to reductions in adult wages of about $8 \%$ and $14 \%$ in Ethiopia and Eritrea, respectively. ${ }^{16}$

Identifying the specific mechanisms by which conflicts affect the health of children remains a challenge that future research will need to address. By examining several health-seeking behaviors as well as indicators of maternal stressors, we found suggestive evidence that conflict exposed children were less likely to be delivered at hospitals, indicating health service delivery might have been compromised in the conflict areas. Furthermore, conflict exposure led to children being more likely to be very small at birth and mothers being more likely to experience amenorrhea. These disruptions in health care delivery and added maternal stressors could explain the negative height effects observed for conflict exposed children. From a policy standpoint, these results suggest households may not have adequate coping mechanisms for conflicts that disrupt economic conditions and lead to displacement, even if the number of civilian casualties is limited. The results also reinforce the importance of considering medium- and longer-term health consequences when designing and implementing post-conflict services.

\footnotetext{
${ }^{16}$ We base this rough back-of-the-envelope calculation on the estimate that a one standard deviation reduction in height correlates with 0.678 fewer grades completed in Zimbabwe (Alderman et al., 2006) and that the return to an extra year of school in Ethiopia is 15\% (Krishnan et al., 1998).
} 


\section{References}

Adhvaryu, Achyuta, James Fenske, and Anant Nyshadham. 2016. "Early Life Circumstance and Adult Mental Health.” Unpublished manuscript.

Adhvaryu, Achyuta, Prashant Bharadwaj, James Fenske, Anant Nyshadham, and Richard Stanley. 2016. "Dust and Death: Evidence from the West African Harmattan.” Unpublished manuscript.

Aguero, Jorge. 2014. "Long-Term Effect of Climate Change on Health: Evidence from Heat Waves in Mexico.” Inter-American Development Bank Working Paper 481.

Akbulut-Yuksel, Mevlude. 2014. "War During Childhood: The Long Run Effects of Warfare on Health.” Unpublished manuscript.

Akresh, Richard. 2009. "Flexibility of Household Structure: Child Fostering Decisions in Burkina Faso.” Journal of Human Resources, 44(4): 976-997.

Akresh, Richard. 2016. “Climate Change, Conflict, and Children.” Future of Children, 26(1): 51-71.

Akresh, Richard, and Damien de Walque. 2008. “Armed Conflict and Schooling: Evidence from the 1994 Rwandan Genocide.” IZA Discussion Paper 3516.

Akresh, Richard, Leonardo Lucchetti, and Harsha Thirumurthy. 2012. "Wars and Child Health: Evidence from the Eritrean-Ethiopian Conflict”. Journal of Development Economics, 99(2): 330-340.

Akresh, Richard, Philip Verwimp, and Tom Bundervoet. 2011. "Civil War, Crop Failure, and Child Stunting in Rwanda.” Economic Development and Cultural Change, 59(4): 777-810.

Akresh, Richard, Sonia Bhalotra, Marinella Leone, and Una Osili. 2012. "War and Stature: Growing Up During the Nigerian Civil War.” American Economic Review, 102(3): 273-277.

Alderman, Harold and Paul Gertler. 1997. "Family Resources and Gender Differences in Human Capital Investments: The Demand for Children's Medical Care in Pakistan.” In Lawrence Haddad, John Hoddinott, and Harold Alderman, eds., Intrahousehold Resource Allocation in Developing 
Countries: Models, Methods, and Policy. Baltimore and London: Johns Hopkins University Press.

Alderman, Harold, John Hoddinott, and Bill Kinsey. 2006. "Long Term Consequences of Early Childhood Malnutrition.” Oxford Economic Papers, 58(3): 450-474.

Almond, Douglas and Bhashkar Mazumder. 2011. "Health Capital and the Prenatal Environment: The Effect of Ramadan Observance During Pregnancy.” American Economic Journal: Applied Economics, 3(4), 5685.

Almond, Douglas, Janet Currie, and Mariesa Herrmann. 2012. "From Infant to Mother: Early Disease Environment and Future Maternal Health.” Labour Economics, 19(4): 475-483.

Almond, Douglas. 2006. "Is the 1918 Influenza Pandemic Over? Long-term Effects of In Utero Influenza Exposure in the Post-1940 US Population.” Journal of Political Economy, 114(4): 672-712.

Angrist, Joshua. 1990. "Lifetime Earnings and the Vietnam Era Draft Lottery: Evidence from Social Security Administrative Records.” American Economic Review, 80(3): 313-336.

Baez, Javier. 2011. "Civil Wars Beyond Their Borders: The Human Capital and Health Consequences of Hosting Refugees.” Journal of Development Economics, 96(2): 391-408.

Barker, David J.P. 1995. “Fetal Origins of Coronary Heart Disease.” British Medical Journal, 311(6998): 171-174.

Bellows, John, and Miguel, Edward. 2009. "War and Local Collective Action in Sierra Leone.” Journal of Public Economics, 93(11-12): 1144-1157.

Bhalotra, Sonia and Atheendar Venkataramani. 2012. "Shadows of the Captain of the Men of Death: Early Life Health Interventions, Human Capital Investments, and Institutions.” University of Essex manuscript.

Blattman, Christopher, and Jeannie Annan. 2010. "The Consequences of Child Soldiering.” Review of Economics and Statistics, 92(4): 882-898. 
Bleakley, Hoyt. 2007. Disease and Development: Evidence from Hookworm Eradication in the American South.” Quarterly Journal of Economics, 122(1): 73-117.

Brakman, Steven, Harry Garretsen, and Marc Schramm. 2004. “The Strategic Bombing of German Cities During World War II and Its Impact on City Growth.” Journal of Economic Geography, 4(2): 201-218

Bruck, Tilman, Patricia Justino, Philip Verwimp, Andrew Tedesco, and Alexandra Avdeenko. 2013. "Measuring Conflict Exposure in MicroLevel Surveys.” Households in Conflict Network Working Paper 153.

Bundervoet, Tom, Philip Verwimp, and Richard Akresh. 2009. "Health and Civil War in Rural Burundi.” Journal of Human Resources, 44(2): 536-563.

Burke, Marshall, Solomon Hsiang, and Edward Miguel. 2015. "Climate and Conflict.” Annual Review of Economics, 7: 577-617.

Caruso, German. 2014a. "Intergenerational Transmission of Shocks in Early Life: Evidence from the Tanzania Great Flood of 1993.” Unpublished manuscript.

Caruso, German. 2014b. "The Legacy of Natural Disasters: The Intergenerational Impact of 100 Years of Natural Disasters in Latin America.” Unpublished manuscript.

Case, Anne, Angela Fertig, and Christina Paxson. 2005. "The Lasting Impact of Childhood Health and Circumstance.” Journal of Health Economics, 24(2): 365-389.

Collier, Paul, and Anke Hoeffler. 1998. "On the Economic Causes of Civil War.” Oxford Economic Papers, 50(4): 563-573.

Currie, Janet and Maya Rossin-Slater. 2013. "Weathering the Storm: Hurricanes and Birth Outcomes." Journal of Health Economics, 32(3): 487-503.

Currie, Janet and Tom Vogl. 2013. "Early-Life Health and Adult Circumstance in Developing Countries.” Annual Review of Economics, 5(1): 1-36. 
Currie, Janet, Matthew Neidell, and Johannes Schmieder. 2009. "Air Pollution and Infant Health: Lessons from New Jersey.” Journal of Health Economics, 28(3): 688-703.

Davis, Donald, and David Weinstein. 2002. "Bones, Bombs, and Break Points: The Geography of Economic Activity.” American Economic Review, 92(5): 1269-1289.

Duflo, Esther. 2003. "Grandmothers and Granddaughters: Old Age Pension and Intrahousehold Allocation in South Africa." World Bank Economic Review: 17(1), 1-25.

Dercon, Stefan and Catherine Porter. 2014. "Live Aid Revisited: Long-Term Impacts of the 1984 Ethiopian Famine on Children.” Journal of the European Economic Association, 12(4): 927-948.

Do, Quy-Toan, and Lakshmi Iyer. 2010. "Geography, Poverty and Conflict in Nepal.” Journal of Peace Research, 47(6): 735-748.

Endara, Skye, Margaret Ryan, Carter Sevick, Ava Marie Conlin, Caroline Macera, and Tyler Smith. 2009. "Does Acute Maternal Stress in Pregnancy Affect Infant Health Outcomes? Examination of a Large Cohort of Infants Born After the Terrorist Attacks of September 11, 2001.” BMC Public Health, 9(252): doi: 10.1186/1471-2458-9-252.

Eritrea Ethiopia Claims Commission. 2005. "Partial Award Jus Ad Bellum Ethiopia's Claims 1-8 between The Federal Democratic Republic of Ethiopia and The State of Eritrea.” The Hague, December 19, 2005.

Fletcher, Jason. 2014. "Examining the Long Term Mortality Effects of Early Health Shocks.” U.S. Census Bureau Center for Economic Studies Paper No 14-19.

Global IDP Project. 2004a. "Profile of Internal Displacement: Eritrea, Compilation of the Information Available in the Global IDP Database of the Norwegian Refugee Council.”

Global IDP Project. 2004b. "Profile of Internal Displacement: Ethiopia, Compilation of the Information Available in the Global IDP Database of the Norwegian Refugee Council.” 
Harari, Mariaflavia and Eliana La Ferrara. 2013. "Conflict, Climate and Cells: A Disaggregated Analysis.” CEPR Discussion Paper 9277.

Human Rights Watch. 2003. "The Horn of Africa War: Mass Expulsions and the Nationality Issue.” Human Rights Watch, 15(3A).

Internal Displacement Monitoring Center (IDMC). 2010. "Internal Displacement: Global Overview of Trends and Developments in 2009.”

Jayachandran, Seema. 2009. “Air Quality and Early-Life Mortality: Evidence from Indonesia’s Wildfires.” Journal of Human Resources, 44(4): 916954.

Krishnan, Pramila, Tesfaye Selassie, and Stefan Dercon. 1998. "The Urban Labor Market During Structural Adjustment: Ethiopia 1990-1997.” Report No. WPS 98-9. Center for the Study of African Economies, Oxford University.

Maccini, Sharon, and Dean Yang. 2009. "Under the Weather: Health, Schooling, and Socioeconomic Consequences of Early-Life Rainfall.” American Economic Review, 99(3): 1006-1026.

Maluccio, John, John Hoddinott, Jere Behrman, Reynaldo Martorell, Agnes Quisumbing, and Aryeh Stein. 2009. "The Impact of Improving Nutrition During Early Childhood on Education among Guatemalan Adults.” Economic Journal, 119(537): 734-763.

Mansour, Hani and Daniel Rees. 2012. "Armed Conflict and Birth Weight: Evidence from the Al-Aqsa Intifada.” Journal of Development Economics, 99(1): 190-199.

Miguel, Edward, and Gerard Roland. 2011. “The Long Run Impact of Bombing Vietnam.” Journal of Development Economics, 96(1): 1-15.

Miguel, Edward, Shanker Satyanath, and Ernest Sergenti. 2004. "Economic Shocks and Civil Conflict: An Instrumental Variables Approach.” Journal of Political Economy, 114(4): 725-753.

Moulton, Brent. 1986. "Random Group Effects and the Precision of Regression Estimates.” Journal of Econometrics, 32(3): 385-397. 
Nilsson, J Peter. 2009. “The Long-term Effects of Early Childhood Lead Exposure: Evidence from the Phase-out of Leaded Gasoline.” Institute for Labor Market Policy Evaluation (IFAU) Working Paper.

Raleigh, Clionadh, Andrew Linke, Havard Hegre, and Joakim Karlsen. 2010. "Introducing ACLED: An Armed Conflict Location and Event Dataset," Journal of Peace Research, 47(5): 651-660.

Rosales-Rueda, Maria Fernanda. 2014. "Impact of Early Life Shocks on Human Capital Formation: Evidence from El Nino Floods in Ecuador.” University of California Irvine working paper.

Rose, Elaina. 1999. "Consumption Smoothing and Excess Female Mortality in Rural India.” Review of Economics and Statistics, 81 (1): 41-49.

Shah, Manisha and Bryce Millett Steinberg. Forthcoming. "Drought of Opportunities: Contemporaneous and Long Term Impacts of Rainfall Shocks on Human Capital.” Journal of Political Economy, forthcoming.

Shemyakina, Olga. 2011. "The Effect of Armed Conflict on Accumulation of Schooling: Results from Tajikistan.” Journal of Development Economics, 95(2): 186-200.

Swee, Eik. 2015. “Together or Separate? Post-conflict Partition, Ethnic Homogenization, and the Provision of Public Schooling.” Journal of Public Economics, 128: 1-15.

Strauss, John, and Duncan Thomas. 2008. "Health Over the Life Course.” In Handbook of Development Economics, vol. 4, ed. Paul Schultz and John Strauss, 3375-3474. Amsterdam: North-Holland.

United States Central Intelligence Agency. 2014. "CIA World Factbook” Downloaded from www.cia.gov on October 28, 2014.

Valente, Christine. 2015. "Civil Conflict, Gender-Specific Fetal Loss, and Selection: A New Test of the Trivers-Willard Hypothesis.” Journal of Health Economics, 39(C): 31-50.

World Health Organization. 1995. "Physical Status: The Use and Interpretation of Anthropometry. Report of a WHO Expert Committee.” World Health Organization Technical Report Series 854:1-452. 
Figure 1: Eritrea and Ethiopia Regional Map Indicating Conflict Sites

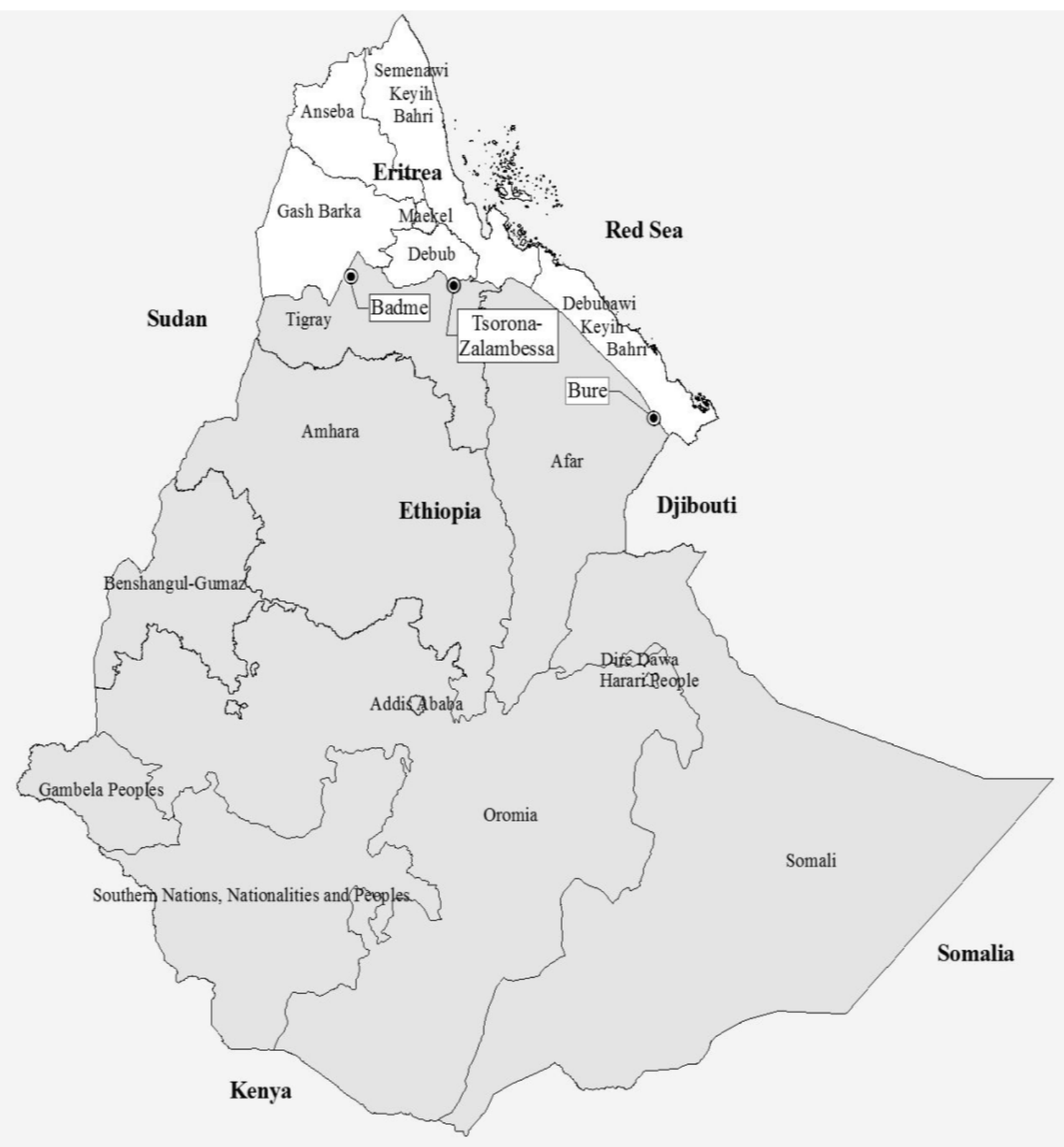

Notes: The main fighting between Eritrea and Ethiopia occurred around the areas of Badme, Tsorona-Zalambessa, and Bure, which are noted on the map. Map source: Constructed by Leonardo Lucchetti and Rafael Garduño-Rivera in ArcGIS. 
Table 1: Child and Household Characteristics, By Proximity to Conflict Sites

\begin{tabular}{|c|c|c|c|c|c|c|}
\hline & \multicolumn{3}{|c|}{ Ethiopia } & \multicolumn{3}{|c|}{ Eritrea } \\
\hline & $\begin{array}{l}\text { Near to } \\
\text { Conflict } \\
\text { Sites } \\
\text { (1) }\end{array}$ & $\begin{array}{l}\text { Not Near } \\
\text { to } \\
\text { Conflict } \\
\text { Sites } \\
(2) \\
\end{array}$ & Difference & $\begin{array}{l}\text { Near to } \\
\text { Conflict } \\
\text { Sites } \\
\text { (4) }\end{array}$ & $\begin{array}{l}\text { Not Near } \\
\text { to } \\
\text { Conflict } \\
\text { Sites } \\
\text { (5) }\end{array}$ & Difference \\
\hline \multicolumn{7}{|l|}{ Panel A: Child Characteristics } \\
\hline Height-for-age Z-score & $\begin{array}{r}-2.043 \\
{[0.050]}\end{array}$ & $\begin{array}{r}-1.770 \\
{[0.015]}\end{array}$ & $\begin{array}{l}0.273^{* * *} \\
{[0.062]}\end{array}$ & $\begin{array}{r}-1.602 \\
{[0.033]}\end{array}$ & $\begin{array}{c}-1.551 \\
{[0.029]}\end{array}$ & $\begin{array}{c}0.052 \\
{[0.044]}\end{array}$ \\
\hline Male & $\begin{array}{r}0.478 \\
{[0.018]}\end{array}$ & $\begin{array}{r}0.507 \\
{[0.004]}\end{array}$ & $\begin{array}{c}0.029 \\
{[0.018]}\end{array}$ & $\begin{array}{r}0.514 \\
{[0.011]}\end{array}$ & $\begin{array}{c}0.523 \\
{[0.009]}\end{array}$ & $\begin{array}{c}0.009 \\
{[0.014]}\end{array}$ \\
\hline Age in Years & $\begin{array}{r}2.130 \\
{[0.049]}\end{array}$ & $\begin{array}{r}2.015 \\
{[0.012]}\end{array}$ & $\begin{array}{l}-0.114 * * \\
{[0.515]}\end{array}$ & $\begin{array}{r}2.035 \\
{[0.031]}\end{array}$ & $\begin{array}{c}2.041 \\
{[0.027]}\end{array}$ & $\begin{array}{c}0.006 \\
{[0.041]}\end{array}$ \\
\hline \multicolumn{7}{|c|}{ Panel B: Household Characteristics } \\
\hline Household Head Is Male & $\begin{array}{c}0.759 \\
{[0.015]}\end{array}$ & $\begin{array}{r}0.851 \\
{[0.003]}\end{array}$ & $\begin{array}{c}0.092 * * * \\
{[0.013]}\end{array}$ & $\begin{array}{r}0.555 \\
{[0.011]}\end{array}$ & $\begin{array}{c}0.669 \\
{[0.009]}\end{array}$ & $\begin{array}{c}0.113 * * * \\
{[0.014]}\end{array}$ \\
\hline Household Head Age & $\begin{array}{l}42.346 \\
{[0.442]}\end{array}$ & $\begin{array}{r}39.399 \\
{[0.100]}\end{array}$ & $\begin{array}{c}-2.948 * * * \\
{[0.424]}\end{array}$ & $\begin{array}{l}40.689 \\
{[0.300]}\end{array}$ & $\begin{array}{l}41.538 \\
{[0.237]}\end{array}$ & $\begin{array}{l}0.849 * * \\
{[0.377]}\end{array}$ \\
\hline Household Head Years School & $\begin{array}{c}1.029 \\
{[0.084]}\end{array}$ & $\begin{array}{r}2.146 \\
{[0.032]}\end{array}$ & $\begin{array}{c}1.116^{* * *} \\
{[0.134]}\end{array}$ & $\begin{array}{r}1.702 \\
{[0.066]}\end{array}$ & $\begin{array}{c}1.963 \\
{[0.065]}\end{array}$ & $\begin{array}{c}0.260 * * * \\
{[0.094]}\end{array}$ \\
\hline Mother Height (cm) & $\begin{array}{r}155.606 \\
{[0.210]}\end{array}$ & $\begin{array}{r}156.924 \\
{[0.061]}\end{array}$ & $\begin{array}{c}1.318^{* * *} \\
{[2.546]}\end{array}$ & $\begin{array}{r}156.532 \\
{[0.123]}\end{array}$ & $\begin{array}{r}156.062 \\
{[0.110]}\end{array}$ & $\begin{array}{r}-0.470 * * * \\
{[0.166]}\end{array}$ \\
\hline Household Size & $\begin{array}{c}6.365 \\
{[0.020]}\end{array}$ & $\begin{array}{r}6.153 \\
{[0.074]}\end{array}$ & $\begin{array}{l}0.212 * * \\
{[0.085]}\end{array}$ & $\begin{array}{r}6.222 \\
{[0.048]}\end{array}$ & $\begin{array}{c}6.139 \\
{[0.040]}\end{array}$ & $\begin{array}{l}-0.083 \\
{[0.063]}\end{array}$ \\
\hline Number of Children Under 5 & $\begin{array}{c}1.801 \\
{[0.025]}\end{array}$ & $\begin{array}{r}1.763 \\
{[0.007]}\end{array}$ & $\begin{array}{l}-0.039 \\
{[0.028]}\end{array}$ & $\begin{array}{r}1.815 \\
{[0.015]}\end{array}$ & $\begin{array}{c}1.846 \\
{[0.013]}\end{array}$ & $\begin{array}{c}0.031 \\
{[0.020]}\end{array}$ \\
\hline Urban (percentage) & $\begin{array}{c}0.096 \\
{[0.011]}\end{array}$ & $\begin{array}{r}0.181 \\
{[0.003]}\end{array}$ & $\begin{array}{c}0.085 * * * \\
{[0.014]}\end{array}$ & $\begin{array}{r}0.211 \\
{[0.009]}\end{array}$ & $\begin{array}{c}0.315 \\
{[0.009]}\end{array}$ & $\begin{array}{c}0.105^{* * *} \\
{[0.012]}\end{array}$ \\
\hline Observations & 780 & 13,056 & & 2,204 & 2,935 & \\
\hline $\begin{array}{l}\text { Notes: Robust standard errors } \\
\text { significant at } 5 \% \text {, and } * * * \text { sign } \\
\text { km from any of the three confl } \\
\text { than } 100 \mathrm{~km} \text { from any of the th } \\
\text { Demographic and Health Surve }\end{array}$ & $\begin{array}{l}\text { brackets, cl } \\
\text { cant at } 1 \% \text {. } \\
\text { sites. "Not } \\
\text { e conflict s } \\
\text {. }\end{array}$ & $\begin{array}{l}\text { t Near to Co } \\
\text { sites. Data sc }\end{array}$ & flict Sites" & ates a cl & $\begin{array}{l}\text { icant at } \\
\text { d living } \mathrm{v} \\
\text { living fa } \\
\text { and } 2005\end{array}$ & $\begin{array}{l}\%, * * \\
\text { hin } 100 \\
\text { ler away } \\
\text { thiopia }\end{array}$ \\
\hline
\end{tabular}


Table 2: Impacts of War Exposure on Children's Height-for-age Z-score, Using Conflict Region

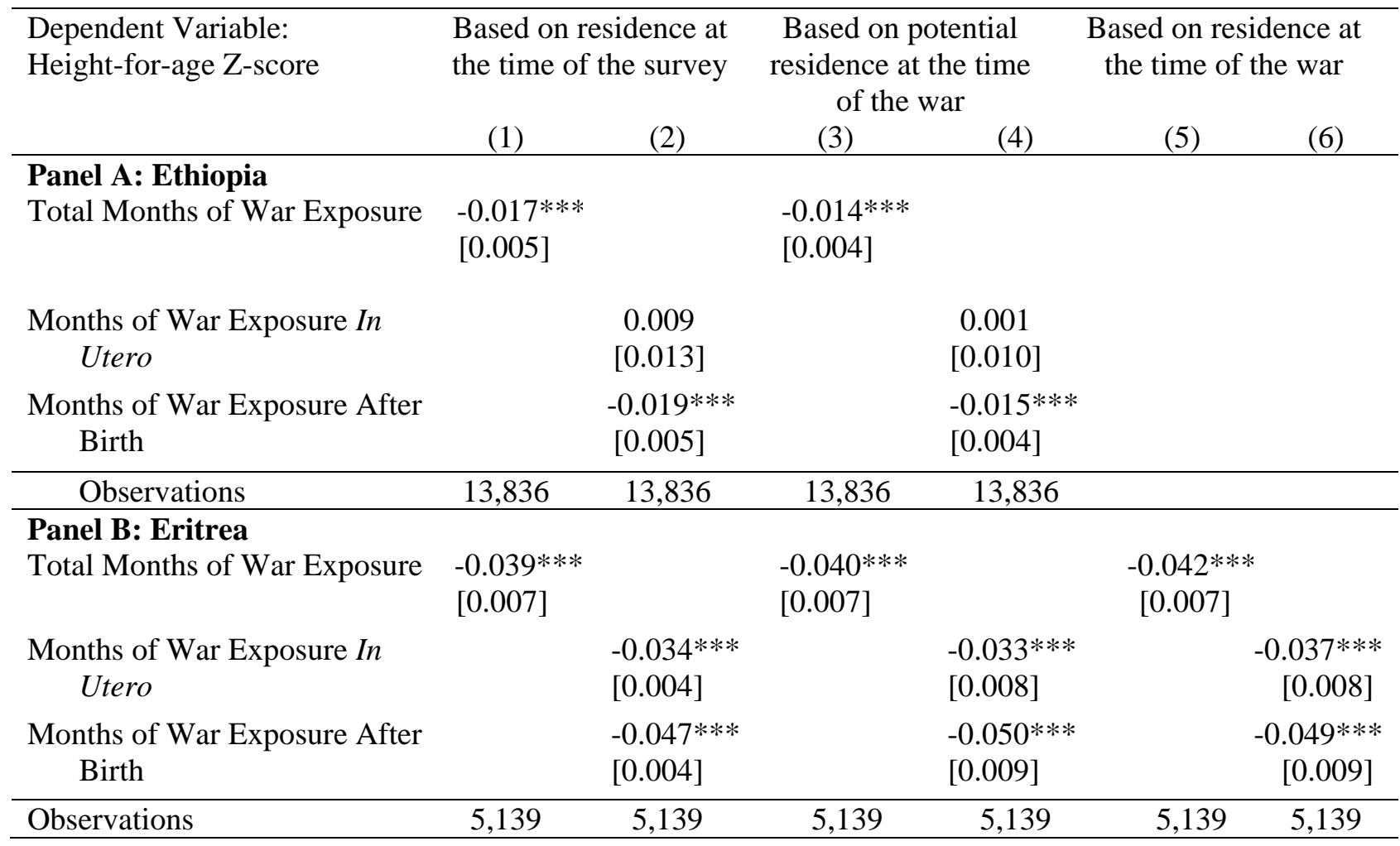

Notes: Robust standard errors in brackets, clustered at the enumeration level. * significant at $10 \%, * *$ significant at $5 \%$, and $* * *$ significant at $1 \%$. All specifications include child age fixed effects, region fixed effects, region-specific time trends, DHS round fixed effects (for Ethiopia), child gender, and controls for household characteristics (noted in the text). In columns 1 and 2, the child's place of residence is based on the region of residence at the time of the survey. In columns 3 and 4, the child's place of residence is based on the potential region of residence at the time of the war, whereby any child who moved during the war is reassigned to a war region regardless of residence at the time of the survey (i.e. for every child who moved during the war and is currently residing in a non-war region, we reassign exposure status as if the child had been living in a war region during the war). This is a conservative approach to dealing with the bias due to endogenous migration as some children who moved during the war and currently reside in a non-war region might have been living in another non-war region during the war. In columns 5 and 6, the child's place of residence is based on the region of residence at the start of the war (information which is only available in the Eritrea data). The war regions in Ethiopia are Tigray and Afar. The war regions in Eritrea are Gash Barka, Debub, and Debubawi Keyih Bahri. "Total months of war exposure” measures the number of months a child was alive or in utero during the war period and living in a war region. "Months of war exposure in utero" measures the number of months a child was in utero during the war period and living in a war region. "Months of war exposure after birth" measures the number of months a child was alive during the war period and living in a war region. Data source: 2002 Eritrea and 2000 and 2005 Ethiopia Demographic and Health Surveys. 
Table 3: Impacts of War Exposure on Children's Height-for-age Z-score, Using War Intensity

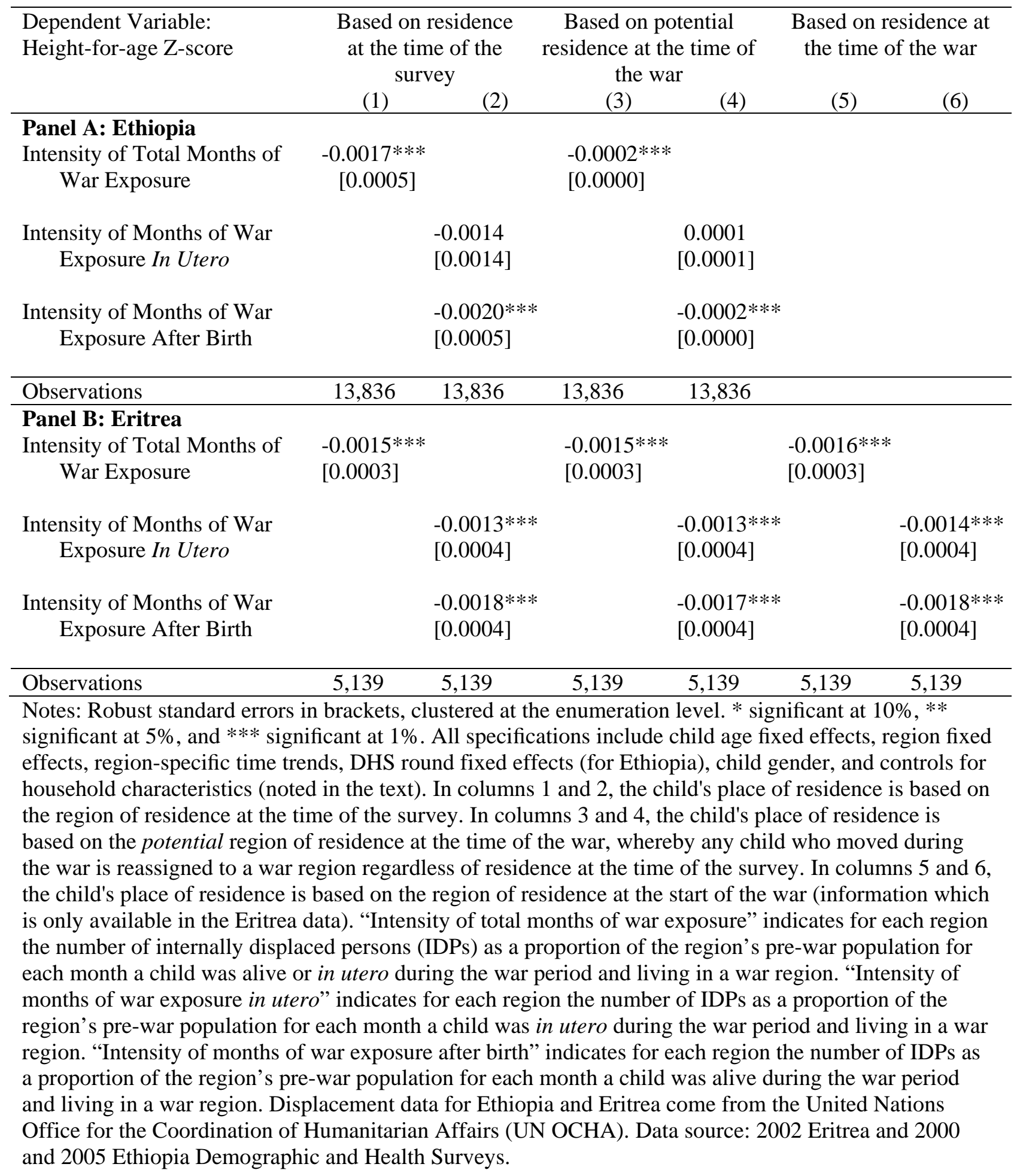


Table 4: Impacts of War Exposure on Children's Height-for-age Z-score, Using GPS Location

\begin{tabular}{|c|c|c|c|c|}
\hline \multirow[t]{2}{*}{$\begin{array}{l}\text { Dependent Variable: } \\
\text { Height-for-age Z-score }\end{array}$} & \multicolumn{2}{|c|}{$\begin{array}{l}\text { Based on residence at } \\
\text { the time of the survey }\end{array}$} & \multicolumn{2}{|c|}{$\begin{array}{l}\text { Based on potential residence } \\
\text { at the time of the war }\end{array}$} \\
\hline & $\begin{array}{c}\text { Ethiopia } \\
\text { (1) }\end{array}$ & $\begin{array}{c}\text { Eritrea } \\
\text { (2) }\end{array}$ & $\begin{array}{c}\text { Ethiopia } \\
\text { (3) }\end{array}$ & $\begin{array}{c}\text { Eritrea } \\
(4)\end{array}$ \\
\hline $\begin{array}{l}\text { Panel A: Total Months of War Exposure } \\
\text { Total Months of War Exposure (by Relative } \\
\text { Proximity) }\end{array}$ & $\begin{array}{l}-0.004^{* * *} \\
{[0.001]}\end{array}$ & $\begin{array}{l}-0.015^{* * *} \\
{[0.002]}\end{array}$ & $\begin{array}{l}-0.003^{* * *} \\
{[0.001]}\end{array}$ & $\begin{array}{l}-0.007 * * * \\
{[0.002]}\end{array}$ \\
\hline Observations & 13,836 & 5,139 & 13,836 & 5,139 \\
\hline $\begin{array}{l}\text { Panel B: Months in utero/after birth } \\
\text { Months of War Exposure In Utero (by } \\
\text { Relative Proximity) }\end{array}$ & $\begin{array}{l}-0.003 * * \\
{[0.001]}\end{array}$ & $\begin{array}{l}-0.021 * * * \\
{[0.003]}\end{array}$ & $\begin{array}{l}-0.002 \\
{[0.001]}\end{array}$ & $\begin{array}{l}-0.020 * * * \\
{[0.003]}\end{array}$ \\
\hline $\begin{array}{l}\text { Months of War Exposure After Birth (by } \\
\text { Relative Proximity) }\end{array}$ & $\begin{array}{l}-0.004 * * * \\
{[0.001]}\end{array}$ & $\begin{array}{l}-0.011 * * * \\
{[0.003]}\end{array}$ & $\begin{array}{c}-0.003^{* * *} \\
{[0.001]}\end{array}$ & $\begin{array}{l}-0.005^{* * *} \\
{[0.002]}\end{array}$ \\
\hline Observations & 13,836 & 5,139 & 13,836 & 5,139 \\
\hline $\begin{array}{l}\text { Notes: Robust standard errors in brackets, clu } \\
\text { significant at } 5 \% \text {, and } * * * \text { significant at } 1 \% \text {. } \\
\text { effects, region-specific time trends, DHS rou } \\
\text { household characteristics (noted in the text). } \\
\text { the residence at the time of the survey. In col } \\
\text { potential residence at the time of the war, wh } \\
\text { have been living at a conflict site. This impli } \\
\text { kilometers to the conflict site and that the pro } \\
\text { children. "Total months of war exposure" me } \\
\text { during the war period by proximity to conflic } \\
\text { Ethiopia Demographic and Health Surveys. }\end{array}$ & $\begin{array}{l}\text { ered at the e } \\
\text { specificatio } \\
\text { fixed effects } \\
\text { columns } 1 \text { a } \\
\text { ans } 3 \text { and } 4 \text {, } \\
\text { eby any chil } \\
\text { hat the migı } \\
\text { mity measur } \\
\text { ures the num } \\
\text { ites. Data so }\end{array}$ & $\begin{array}{l}\text { umeration le } \\
\text { s include ch } \\
\text { (for Ethiopic } \\
\text { d 2, the chil } \\
\text { e child's pla } \\
\text { who moved } \\
\text { nt child is as } \\
\text { will attain i } \\
\text { er of month }\end{array}$ & $\begin{array}{l}\text { * significant } \\
\text { age fixed effe } \\
\text { child gender, } \\
\text { place of resid } \\
\text { of residence i } \\
\text { ring the war is } \\
\text { gned a distanc } \\
\text { argest possibl } \\
\text { child was ali } \\
\text { ea and } 2000 \text { a }\end{array}$ & $\begin{array}{l}10 \%, * * \\
\text { region fixed } \\
\text { controls for } \\
\text { e is based on } \\
\text { sed on the } \\
\text { sumed to } \\
0 \\
0 \\
\text { lue for these } \\
\text { in utero } \\
2005\end{array}$ \\
\hline
\end{tabular}


Table 5: Impacts of War Exposure on Children's Height-for-age Z-score, Using GPS Location (By Gender)

\begin{tabular}{|c|c|c|c|c|}
\hline \multirow[t]{2}{*}{ Dependent Variable: Height-for-age Z-score } & \multicolumn{2}{|c|}{ Female } & \multicolumn{2}{|c|}{ Male } \\
\hline & $\begin{array}{c}\text { Ethiopia } \\
\text { (1) }\end{array}$ & $\begin{array}{c}\text { Eritrea } \\
(2)\end{array}$ & $\begin{array}{c}\text { Ethiopia } \\
\text { (3) }\end{array}$ & $\begin{array}{c}\text { Eritrea } \\
(4)\end{array}$ \\
\hline \multicolumn{5}{|l|}{ Panel A: Total Months of War Exposure } \\
\hline Total Months of War Exposure (by Relative & $-0.003 * * *$ & $-0.012 * * *$ & $-0.004 * * *$ & $-0.017 * * *$ \\
\hline Proximity) & {$[0.001]$} & [0.003] & {$[0.001]$} & {$[0.003]$} \\
\hline Observations & 6,839 & 2,472 & 6,997 & 2,667 \\
\hline \multicolumn{5}{|l|}{ Panel B: Months in utero/after birth } \\
\hline Months of War Exposure In Utero (by & -0.002 & $-0.020 * * *$ & $-0.004 * * *$ & $-0.022 * * *$ \\
\hline Relative Proximity) & [0.002] & [0.004] & {$[0.002]$} & {$[0.005]$} \\
\hline Months of War Exposure After Birth (by & $-0.003 * * *$ & $-0.007 *$ & $-0.004 * * *$ & $-0.014 * * *$ \\
\hline Relative Proximity) & {$[0.001]$} & [0.004] & {$[0.001]$} & {$[0.004]$} \\
\hline Observations & 6,839 & 2,472 & 6,997 & 2,667 \\
\hline \multicolumn{5}{|c|}{$\begin{array}{l}\text { Notes: Robust standard errors in brackets, clustered at the enumeration level. * significant at } 10 \%, * * \\
\text { significant at } 5 \% \text {, and } * * * \text { significant at } 1 \% \text {. All specifications include child age fixed effects, region fixed } \\
\text { effects, region-specific time trends, DHS round fixed effects (for Ethiopia), child gender, and controls for } \\
\text { household characteristics (noted in the text). In all regressions, the child's place of residence is based on } \\
\text { the region of residence at the time of the survey. "Total months of war exposure” measures the number of } \\
\text { months a child was alive or in utero during the war period by proximity to conflict sites. Data source: } \\
2002 \text { Eritrea and } 2000 \text { and } 2005 \text { Ethiopia Demographic and Health Surveys. }\end{array}$} \\
\hline
\end{tabular}


Table 6: Impacts of War Exposure on Potential Mechanisms

\begin{tabular}{lccccc}
\hline Dependent Variable: & $\begin{array}{c}\text { Delivery at } \\
\text { Hospital }\end{array}$ & $\begin{array}{c}\text { Drinks } \\
\text { Alcohol } \\
\text { During } \\
\text { Pregnancy } \\
(2)\end{array}$ & $\begin{array}{c}\text { Bed Net } \\
\text { Usage }\end{array}$ & $\begin{array}{c}\text { Small } \\
\text { Birth } \\
\text { Size }\end{array}$ & $\begin{array}{c}\text { Duration of } \\
\text { Postpartum } \\
\text { Amenorrhea } \\
\text { (in months) } \\
(5)\end{array}$ \\
\hline $\begin{array}{l}\text { Panel A: Ethiopia } \\
\begin{array}{l}\text { Total Months of War Exposure } \\
\text { (by Relative Proximity) }\end{array}\end{array}$ & $\begin{array}{c}-0.030^{* * *} \\
{[0.011]}\end{array}$ & $\begin{array}{c}0.024^{* * *} \\
{[0.002]}\end{array}$ & $\begin{array}{c}0.000 \\
{[0.000]}\end{array}$ & $\begin{array}{c}0.103^{* * *} \\
{[0.015]}\end{array}$ & $\begin{array}{c}0.023^{* * *} \\
{[0.004]}\end{array}$ \\
\hline Observations & 13,722 & 9,181 & 13,829 & 13,836 & 13,330 \\
\hline $\begin{array}{l}\text { Panel B: Eritrea } \\
\text { Total Months of War Exposure } \\
\text { (by Relative Proximity) }\end{array}$ & 0.064 & $0.011^{* * *}$ & $-0.003^{* * *}$ & 0.039 & $0.076^{* * *}$ \\
& {$[0.055]$} & {$[0.004]$} & {$[0.001]$} & {$[0.035]$} & {$[0.012]$} \\
\hline Observations & 5,132 & 4,090 & 5,137 & 5,139 & 4,926 \\
\hline
\end{tabular}

Notes: Robust standard errors in brackets, clustered at the enumeration level. * significant at $10 \%, * *$ significant at $5 \%$, and $* * *$ significant at $1 \%$. All specifications include child age fixed effects, region fixed effects, region-specific time trends, DHS round fixed effects (for Ethiopia), child gender, and controls for household characteristics (noted in the text). "Delivery at hospital" indicates the percentage of children who were delivered at a hospital or health clinic (means: Ethiopia=12\%, Eritrea=22\%). "Drinks Alcohol during Pregnancy" indicates how many times the mother drank alcohol during pregnancy (means: Ethiopia=3.2, Eritrea=2.9). "Bed Net Usage" indicates the percentage of children that have a bed net available to use while sleeping (means: Ethiopia=5.9\%, Eritrea=45.8\%). "Small birth size" indicates the percentage of children recorded as very small at birth (means: Ethiopia=10.0\%, Eritrea=4.1\%). "Duration of postpartum amenorrhea" measures the number of postpartum months the mother experienced amenorrhea (means: Ethiopia=9.9, Eritrea=11.5). The child's place of residence is based on the region of residence at the time of the survey. "Total months of war exposure" measures the number of months a child was alive or in utero during the war period by proximity to conflict sites. Data source: 2002 Eritrea and 2000 and 2005 Ethiopia Demographic and Health Surveys. 


\section{Appendix Table 1: Impacts in Ethiopia and Eritrea of War Exposure on Children's Height-for-age Z-score, Using Conflict Region}

\begin{tabular}{|c|c|c|c|c|}
\hline \multirow[t]{2}{*}{$\begin{array}{l}\text { Dependent Variable: } \\
\text { Height-for-age Z-score }\end{array}$} & \multicolumn{2}{|c|}{$\begin{array}{l}\text { Based on residence at } \\
\text { the time of the survey }\end{array}$} & \multicolumn{2}{|c|}{$\begin{array}{l}\text { Based on potential } \\
\text { residence at the time of } \\
\text { the war }\end{array}$} \\
\hline & $(1)$ & $(2)$ & (3) & (4) \\
\hline Total Months of War Exposure * Eritrea & $\begin{array}{l}-0.023 * * * \\
{[0.005]}\end{array}$ & & $\begin{array}{l}-0.027 * * * \\
{[0.004]}\end{array}$ & \\
\hline Months of War Exposure In Utero * Eritrea & & $\begin{array}{l}-0.043^{* * *} \\
{[0.013]}\end{array}$ & & $\begin{array}{l}-0.046^{* * *} \\
{[0.009]}\end{array}$ \\
\hline Months of War Exposure After Birth * Eritrea & & $\begin{array}{l}-0.028^{* * *} \\
{[0.005]}\end{array}$ & & $\begin{array}{l}-0.035^{* * * *} \\
{[0.010]}\end{array}$ \\
\hline Total Months of War Exposure & $\begin{array}{l}-0.017 * * * \\
{[0.005]}\end{array}$ & & $\begin{array}{l}-0.014 * * * \\
{[0.004]}\end{array}$ & \\
\hline Months of War Exposure In Utero & & $\begin{array}{c}0.009 \\
{[0.013]}\end{array}$ & & $\begin{array}{l}0.013 * * * \\
{[0.000]}\end{array}$ \\
\hline Months of War Exposure After Birth & & $\begin{array}{l}-0.019 * * * \\
{[0.005]}\end{array}$ & & $\begin{array}{l}-0.017 * * * \\
{[0.000]}\end{array}$ \\
\hline Observations & 18,975 & 18,975 & 18,975 & 18,975 \\
\hline
\end{tabular}

Notes: Robust standard errors in brackets, clustered at the enumeration level. * significant at $10 \%, * *$ significant at $5 \%$, and $* * *$ significant at $1 \%$. All specifications include child age fixed effects, region fixed effects, region-specific time trends, DHS round fixed effects (for Ethiopia), child gender, and controls for household characteristics (noted in the text). In addition, interactions of all of these variables with Eritrea were also included in the regressions. In columns 1 and 2, the child's place of residence is based on the region of residence at the time of the survey. In columns 3 and 4, the child's place of residence is based on the potential region of residence at the time of the war, whereby any child who moved during the war is reassigned to a war region regardless of residence at the time of the survey. The war regions in Ethiopia are Tigray and Afar. The war regions in Eritrea are Gash Barka, Debub, and Debubawi Keyih Bahri. "Total months of war exposure" measures the number of months a child was alive or in utero during the war period and living in a war region. "Months of war exposure in utero" measures the number of months a child was in utero during the war period and living in a war region. "Months of war exposure after birth" measures the number of months a child was alive during the war period and living in a war region. "Eritrea" indicates a child living in Eritrea. Data source: 2002 Eritrea and 2000 and 2005 Ethiopia Demographic and Health Surveys. 


\section{Appendix Table 2: Impacts in Ethiopia and Eritrea of War Exposure on Children's Height-for-age Z-score, Using GPS Location}

\begin{tabular}{lcc} 
Dependent Variable: Height-for-age Z-score & $\begin{array}{c}\text { Based on } \\
\text { residence at the } \\
\text { time of the survey } \\
(1)\end{array}$ & $\begin{array}{c}\text { Based on potential } \\
\text { residence at the time } \\
\text { of the war } \\
(2)\end{array}$ \\
\hline Panel A: Total Months of exposure & $-0.012^{* * *}$ & $-0.009^{* * *}$ \\
Total Months of War Exposure (by Relative Proximity) & {$[0.001]$} & {$[0.001]$} \\
$\quad *$ Eritrea & $-0.003^{* * *}$ & $-0.003^{* * *}$ \\
Total Months of War Exposure (by Relative Proximity) & {$[0.001]$} & {$[0.001]$} \\
& & \\
\hline Observations & 18,975 & 18,975 \\
\hline Panel B: Months in/after birth & $-0.020^{* * *}$ & $-0.021^{* * *}$ \\
Months of War Exposure In Utero (by Relative Proximity) & {$[0.001]$} & {$[0.003]$} \\
$\quad *$ Eritrea & $-0.008^{* * *}$ & $-0.005^{* *}$ \\
Months of War Exposure After Birth (by Relative Proximity) & {$[0.001]$} & {$[0.003]$} \\
$\quad *$ Eritrea & $-0.001^{*}$ & $-0.001^{* * *}$ \\
Months of War Exposure In Utero (by Relative Proximity) & {$[0.001]$} & {$[0.000]$} \\
& $-0.003^{* * *}$ & $-0.003^{* * *}$ \\
Months of War Exposure After Birth (by Relative Proximity) & {$[0.001]$} & {$[0.000]$} \\
\hline Observations & 18,975 & 18,975 \\
\hline
\end{tabular}

Notes: Robust standard errors in brackets, clustered at the enumeration level. * significant at $10 \%, * *$ significant at $5 \%$, and $* * *$ significant at $1 \%$. All specifications include child age fixed effects, region fixed effects, region-specific time trends, DHS round fixed effects (for Ethiopia), child gender, and controls for household characteristics (noted in the text). In addition, interactions of all of these variables with Eritrea were also included in the regressions. In column 1, the child's place of residence is based on the region of residence at the time of the survey. In column 2, the child's place of residence is based on the potential residence at the time of the war, whereby any child who moved during the war is assumed to have been living at a conflict site. This implies that the migrant child is assigned a distance of 0 kilometers to the conflict site and that the proximity measure will attain its largest possible value for these children. "Total months of war exposure" measures the number of months a child was alive or in utero during the war period by proximity to conflict sites. Data source: 2002 Eritrea and 2000 and 2005 Ethiopia Demographic and Health Surveys. 


\section{Appendix Table 3: Impacts of War Exposure on Children's Height-for-age Z-score, Including Mother Fixed Effects}

\begin{tabular}{|c|c|c|}
\hline \multirow[t]{2}{*}{ Dependent Variable: Height-for-age Z-score } & \multicolumn{2}{|c|}{ Based on residence at the time of the survey } \\
\hline & $\begin{array}{c}\text { Ethiopia } \\
(1)\end{array}$ & $\begin{array}{l}\text { Eritrea } \\
(2)\end{array}$ \\
\hline Total Months of War Exposure (by Relative Proximity) & $\begin{array}{l}-0.001 * \\
{[0.001]}\end{array}$ & $\begin{array}{l}-0.001 * * * \\
{[0.000]}\end{array}$ \\
\hline Observations & 10,185 & 3,126 \\
\hline
\end{tabular}

Notes: Robust standard errors in brackets, clustered at the enumeration level. * significant at $10 \%$, ** significant at $5 \%$, and $* * *$ significant at $1 \%$. All specifications include mother fixed effects, child age fixed effects, region-specific time trends, and child gender controls. In all columns, the child's place of residence is based on the region of residence at the time of the survey. "Total months of war exposure" measures the number of months a child was alive or in utero during the war period by proximity to conflict sites. Data source: 2002 Eritrea and 2000 and 2005 Ethiopia Demographic and Health Surveys. 


\section{Appendix Table 4a: Impacts of War Exposure on Children's Height-for-age Z-score, Using GPS Location}

\begin{tabular}{|c|c|c|c|c|}
\hline \multirow[t]{2}{*}{$\begin{array}{l}\text { Dependent Variable: } \\
\text { Height-for-age Z-score }\end{array}$} & \multicolumn{2}{|c|}{$\begin{array}{l}\text { Based on residence at } \\
\text { the time of the survey }\end{array}$} & \multicolumn{2}{|c|}{$\begin{array}{l}\text { Based on potential residence } \\
\text { at the time of the war }\end{array}$} \\
\hline & $\begin{array}{c}\text { Ethiopia } \\
\text { (1) }\end{array}$ & $\begin{array}{c}\text { Eritrea } \\
(2)\end{array}$ & $\begin{array}{c}\text { Ethiopia } \\
\text { (3) }\end{array}$ & $\begin{array}{c}\text { Eritrea } \\
(4)\end{array}$ \\
\hline $\begin{array}{l}\text { Panel A: Total Months of War Exposure } \\
\text { Total Months of War Exposure (0-100 km) }\end{array}$ & $\begin{array}{l}-0.049 * * * \\
{[0.012]}\end{array}$ & $\begin{array}{l}-0.073^{* * *} \\
{[0.022]}\end{array}$ & $\begin{array}{l}-0.010 * * \\
{[0.005]}\end{array}$ & $\begin{array}{l}-0.090^{* * *} \\
{[0.015]}\end{array}$ \\
\hline Total Months of War Exposure (100-200 km) & $\begin{array}{l}-0.033 * * \\
{[0.016]}\end{array}$ & $\begin{array}{l}-0.059 * * * \\
{[0.008]}\end{array}$ & $\begin{array}{l}-0.013 \\
{[0.008]}\end{array}$ & $\begin{array}{l}-0.054^{* * *} \\
{[0.007]}\end{array}$ \\
\hline Total Months of War Exposure (200-300 km) & $\begin{array}{l}-0.015^{*} \\
{[0.009]}\end{array}$ & $\begin{array}{l}-0.056 * * * \\
{[0.008]}\end{array}$ & $\begin{array}{l}-0.004 \\
{[0.005]}\end{array}$ & $\begin{array}{l}-0.045^{* * *} \\
{[0.007]}\end{array}$ \\
\hline Observations & 13,836 & 5,139 & 13,836 & 5,139 \\
\hline $\begin{array}{l}\text { P-value testing equality between proximity } \\
\quad \text { variables: } \\
0-100 \mathrm{~km}=200-300 \mathrm{~km} \\
0-100 \mathrm{~km}=100-200 \mathrm{~km} \\
100-200 \mathrm{~km}=200-300 \mathrm{~km}\end{array}$ & $\begin{array}{l}0.013 \\
0.403 \\
0.294\end{array}$ & $\begin{array}{l}0.468 \\
0.568 \\
0.708\end{array}$ & $\begin{array}{l}0.297 \\
0.761 \\
0.336\end{array}$ & $\begin{array}{l}0.001 \\
0.012 \\
0.069\end{array}$ \\
\hline $\begin{array}{l}\text { Notes: Robust standard errors in brackets, clust } \\
\text { significant at } 5 \% \text {, and } * * * \text { significant at } 1 \% \text {. Al } \\
\text { effects, region-specific time trends, DHS round } \\
\text { household characteristics (noted in the text). In } \\
\text { the residence at the time of the survey. In colur } \\
\text { potential residence at the time of the war, wher } \\
\text { the closest distance category ( } 0-100 \mathrm{~km} \text { ) regarc } \\
\text { of war exposure" measures the number of mon } \\
\text { living within } 0-100 \mathrm{~km}, 100-200 \mathrm{~km}, 200-300 \\
\text { The reference group is children living more tha } \\
\text { and } 2000 \text { and } 2005 \text { Ethiopia Demographic and }\end{array}$ & $\begin{array}{l}\text { ered at the e } \\
\text { specificatio } \\
\text { fixed effects } \\
\text { columns } 1 \text { a } \\
\text { ns } 3 \text { and } 4 \text {, } \\
\text { aby any chilc } \\
\text { less of resid } \\
\text { hs a child w } \\
\text { an, or more } \\
300 \text { km fro } \\
\text { Health Surve }\end{array}$ & $\begin{array}{l}\text { Imeration le } \\
\text { s include ch } \\
\text { for Ethiopi } \\
\text { 2, the chil } \\
\text { e child's pla } \\
\text { who moved } \\
\text { ice at the tin } \\
\text { alive or in } \\
\text { an } 300 \mathrm{~km} \\
\text { a conflict sit }\end{array}$ & $\begin{array}{l}\text { * significant } \\
\text { age fixed effe } \\
\text { child gender, } \\
\text { place of resid } \\
\text { of residence i } \\
\text { ring the war i } \\
\text { of the survey. } \\
\text { ro during the } \\
\text { pectively fron } \\
\text { Data source: }\end{array}$ & $\begin{array}{l}10 \%, * * \\
\text {, region fixed } \\
\text { l controls for } \\
\text { e is based on } \\
\text { ased on the } \\
\text { assigned to } \\
\text { otal months } \\
\text { r period and } \\
\text { onflict sites. } \\
02 \text { Eritrea }\end{array}$ \\
\hline
\end{tabular}




\section{Appendix Table 4b: Impacts of War Exposure on Children's Height-for-age Z-score, Using GPS Location}

\begin{tabular}{|c|c|c|c|c|}
\hline \multirow[t]{2}{*}{$\begin{array}{l}\text { Dependent Variable: } \\
\text { Height-for-age Z-score }\end{array}$} & \multicolumn{2}{|c|}{$\begin{array}{l}\text { Based on residence at } \\
\text { the time of the survey }\end{array}$} & \multicolumn{2}{|c|}{$\begin{array}{l}\text { Based on potential } \\
\text { residence at the time } \\
\text { of the war }\end{array}$} \\
\hline & $\begin{array}{l}\text { Ethiopia } \\
\text { (1) }\end{array}$ & $\begin{array}{c}\text { Eritrea } \\
(2)\end{array}$ & $\begin{array}{l}\text { Ethiopia } \\
\text { (3) }\end{array}$ & $\begin{array}{c}\text { Eritrea } \\
(4)\end{array}$ \\
\hline \multicolumn{5}{|l|}{ Panel B: Months in utero/after birth } \\
\hline Months of War Exposure In Utero $(0-100 \mathrm{~km})$ & $\begin{array}{l}-0.036 * * \\
{[0.017]}\end{array}$ & $\begin{array}{l}-0.073 * * * \\
{[0.026]}\end{array}$ & $\begin{array}{l}-0.009 \\
{[0.011]}\end{array}$ & $\begin{array}{l}-0.082 * * * \\
{[0.025]}\end{array}$ \\
\hline Months of War Exposure In Utero (100-200 km) & $\begin{array}{l}-0.017 \\
{[0.024]}\end{array}$ & $\begin{array}{l}-0.060^{* * *} \\
{[0.010]}\end{array}$ & $\begin{array}{l}-0.001 \\
{[0.012]}\end{array}$ & $\begin{array}{l}-0.061^{* * *} \\
{[0.010]}\end{array}$ \\
\hline Months of War Exposure In Utero (200-300 km) & $\begin{array}{l}-0.016 \\
{[0.012]}\end{array}$ & $\begin{array}{l}-0.058^{* * *} \\
{[0.009]}\end{array}$ & $\begin{array}{c}0.003 \\
{[0.024]}\end{array}$ & $\begin{array}{l}-0.051 * * * \\
{[0.009]}\end{array}$ \\
\hline Months of War Exposure After Birth (0-100 km) & $\begin{array}{l}-0.055^{* * *} \\
{[0.013]}\end{array}$ & $\begin{array}{l}-0.072^{* *} \\
{[0.029]}\end{array}$ & $\begin{array}{l}-0.011^{* *} \\
{[0.005]}\end{array}$ & $\begin{array}{l}-0.088 * * * \\
{[0.017]}\end{array}$ \\
\hline Months of War Exposure After Birth (100-200 km) & $\begin{array}{l}-0.040^{* *} \\
{[0.016]}\end{array}$ & $\begin{array}{l}-0.059 * * * \\
{[0.010]}\end{array}$ & $\begin{array}{l}-0.014 \\
{[0.008}\end{array}$ & $\begin{array}{l}-0.048 * * * \\
{[0.009]}\end{array}$ \\
\hline Months of War Exposure After Birth (200-300 km) & $\begin{array}{l}-0.014 \\
{[0.009]}\end{array}$ & $\begin{array}{l}-0.053^{* * *} \\
{[0.010]}\end{array}$ & $\begin{array}{l}-0.004 \\
{[0.005]}\end{array}$ & $\begin{array}{l}-0.040^{* * *} \\
{[0.009]}\end{array}$ \\
\hline Observations & 13,836 & 5,139 & 13,836 & 5,139 \\
\hline \multicolumn{5}{|l|}{$\begin{array}{l}\text { P-value testing equality between proximity } \\
\text { variables: }\end{array}$} \\
\hline $0-100 \mathrm{~km}($ in utero $)=200-300 \mathrm{~km}($ in utero $)$ & 0.293 & 0.575 & 0.611 & 0.212 \\
\hline 0-100 km (in utero $)=100-200$ km (in utero) & 0.496 & 0.621 & 0.562 & 0.399 \\
\hline $100-200 \mathrm{~km}($ in utero $)=200-300 \mathrm{~km}($ in utero $)$ & 0.965 & 0.876 & 0.872 & 0.312 \\
\hline 0-100 km (after birth) = 200-300 km (after birth) & 0.004 & 0.510 & 0.220 & 0.002 \\
\hline 0-100 km (after birth) = 100-200 km (after birth) & 0.459 & 0.670 & 0.777 & 0.012 \\
\hline 100-200 km (after birth) = 200-300 km (after birth) & 0.134 & 0.584 & 0.285 & 0.096 \\
\hline \multicolumn{5}{|c|}{$\begin{array}{l}\text { Notes: Robust standard errors in brackets, clustered at the enumeration level. * significant at } 10 \% \text {, ** } \\
\text { significant at } 5 \% \text {, and } * * * \text { significant at } 1 \% \text {. All specifications include child age fixed effects, region fixed } \\
\text { effects, region-specific time trends, DHS round fixed effects (for Ethiopia), child gender, and controls for } \\
\text { household characteristics (noted in the text). In columns } 1 \text { and } 2 \text {, the child's place of residence is based on } \\
\text { the region of residence at the time of the survey. In columns } 3 \text { and } 4 \text {, the child's place of residence is } \\
\text { based on the potential residence at the time of the war, whereby any child who moved during the war is } \\
\text { reassigned to the closest distance category }(0-100 \mathrm{~km} \text { ) regardless of residence at the time of the survey. } \\
\text { "Months of war exposure in utero" measures the number of months a child was in utero during the war } \\
\text { period and living within 0-100 km, } 100-200 \mathrm{~km}, 200-300 \mathrm{~km} \text {, or more than } 300 \mathrm{~km} \text { respectively from } \\
\text { conflict sites. "Months of war exposure after birth" measures the number of months a child was alive } \\
\text { during the war period and living within } 0-100 \mathrm{~km}, 100-200 \mathrm{~km} \text {, } 200-300 \mathrm{~km} \text {, or more than } 300 \mathrm{~km} \\
\text { respectively from conflict sites. The reference group is children living more than } 300 \mathrm{~km} \text { from conflict } \\
\text { sites. Data source: } 2002 \text { Eritrea and } 2000 \text { and } 2005 \text { Ethiopia Demographic and Health Surveys. }\end{array}$} \\
\hline
\end{tabular}


Appendix Table 5: Endogenous Fertility: Characteristics of Women Having a Child During War

\begin{tabular}{|c|c|c|c|c|c|c|}
\hline \multirow[b]{2}{*}{ Dependent Variable: } & \multicolumn{4}{|c|}{ Women's characteristics } & \multicolumn{2}{|c|}{$\begin{array}{l}\text { Household heads' } \\
\text { characteristics }\end{array}$} \\
\hline & $\begin{array}{l}\text { Years of } \\
\text { education } \\
\text { (1) }\end{array}$ & $\begin{array}{l}\text { Number } \\
\text { of births } \\
\text { (2) }\end{array}$ & $\begin{array}{l}\text { Height in } \\
\text { centimeters } \\
\text { (3) }\end{array}$ & $\begin{array}{l}\text { Age } \\
(4)\end{array}$ & $\begin{array}{l}\text { Age } \\
(5)\end{array}$ & $\begin{array}{l}\text { Gender } \\
(6)\end{array}$ \\
\hline Panel A: Ethiopia & & & & & & \\
\hline $\begin{array}{c}\text { War Region * Has a Child } \\
\text { Born During War }\end{array}$ & $\begin{array}{c}0.001 \\
{[0.307]}\end{array}$ & $\begin{array}{l}-0.203 \\
{[0.194]}\end{array}$ & $\begin{array}{l}0.740^{*} \\
{[0.438]}\end{array}$ & $\begin{array}{c}-0.713 \\
{[0.563]}\end{array}$ & $\begin{array}{c}0.234 \\
{[1.005]}\end{array}$ & $\begin{array}{l}-0.024 \\
{[0.037]}\end{array}$ \\
\hline War Region & $\begin{array}{c}2.644 * * * \\
{[0.416]}\end{array}$ & $\begin{array}{c}-0.339 * * \\
{[0.168]}\end{array}$ & $\begin{array}{c}0.128 \\
{[0.413]}\end{array}$ & $\begin{array}{c}0.444 \\
{[0.472]}\end{array}$ & $\begin{array}{c}0.592 \\
{[0.934]}\end{array}$ & $\begin{array}{c}0.015 \\
{[0.034]}\end{array}$ \\
\hline $\begin{array}{l}\text { Has a Child Born During } \\
\text { War }\end{array}$ & $\begin{array}{c}-0.252^{* *} \\
{[0.107]}\end{array}$ & $\begin{array}{c}0.790 * * * \\
{[0.101]}\end{array}$ & $\begin{array}{c}-0.630 * * * \\
{[0.229]}\end{array}$ & $\begin{array}{c}1.169 * * * \\
{[0.302]}\end{array}$ & $\begin{array}{l}-1.000^{*} \\
{[0.561]}\end{array}$ & $\begin{array}{c}0.017 \\
{[0.019]}\end{array}$ \\
\hline Constant & $\begin{array}{c}1.194 * * * \\
{[0.124]}\end{array}$ & $\begin{array}{c}3.610^{* * *} \\
{[0.081]}\end{array}$ & $\begin{array}{c}156.518^{* * *} \\
{[0.228]}\end{array}$ & $\begin{array}{c}29.609 * * * \\
{[0.261]}\end{array}$ & $\begin{array}{c}42.000 * * * \\
{[0.514]}\end{array}$ & $\begin{array}{c}0.592 * * * \\
{[0.020]}\end{array}$ \\
\hline Observations & 6,833 & 6,833 & 6,833 & 6,833 & 6,792 & 6,792 \\
\hline $\begin{array}{l}\text { Panel B: Eritrea } \\
\text { War Region * Has a Child } \\
\quad \text { Born During War }\end{array}$ & $\begin{array}{l}-0.200 \\
{[0.232]}\end{array}$ & $\begin{array}{c}0.205 \\
{[0.172]}\end{array}$ & $\begin{array}{c}0.169 \\
{[0.393]}\end{array}$ & $\begin{array}{c}0.887^{*} \\
{[0.513]}\end{array}$ & $\begin{array}{c}0.320 \\
{[0.947]}\end{array}$ & $\begin{array}{c}-0.050 \\
{[0.033]}\end{array}$ \\
\hline War Region & $\begin{array}{c}-0.771^{* *} \\
{[0.322]}\end{array}$ & $\begin{array}{c}0.053 \\
{[0.143]}\end{array}$ & $\begin{array}{l}-0.067 \\
{[0.391]}\end{array}$ & $\begin{array}{c}-0.660 \\
{[0.438]}\end{array}$ & $\begin{array}{l}-1.587^{*} \\
{[0.877]}\end{array}$ & $\begin{array}{l}-0.013 \\
{[0.033]}\end{array}$ \\
\hline $\begin{array}{l}\text { Has a Child Born During } \\
\text { War }\end{array}$ & $\begin{array}{l}-0.312 * \\
{[0.188]}\end{array}$ & $\begin{array}{c}0.650 * * * \\
{[0.126]}\end{array}$ & $\begin{array}{l}-0.540 * \\
{[0.295]}\end{array}$ & $\begin{array}{c}0.471 \\
{[0.380]}\end{array}$ & $\begin{array}{l}-1.228^{*} \\
{[0.719]}\end{array}$ & $\begin{array}{c}0.036 \\
{[0.025]}\end{array}$ \\
\hline Constant & $\begin{array}{c}2.431 * * * \\
{[0.264]}\end{array}$ & $\begin{array}{c}3.478 * * * \\
{[0.103]}\end{array}$ & $\begin{array}{c}156.594^{* * *} \\
{[0.310]}\end{array}$ & $\begin{array}{c}30.122 * * * \\
{[0.328]}\end{array}$ & $\begin{array}{c}43.088 * * * \\
{[0.691]}\end{array}$ & $\begin{array}{c}0.603 * * * \\
{[0.023]}\end{array}$ \\
\hline Observations & 4,114 & 4,116 & 4,070 & 4,116 & 4,101 & 4,116 \\
\hline
\end{tabular}

Notes: Robust standard errors in brackets, clustered at the enumeration level. * significant at $10 \%$, ** significant at $5 \%$, and $* * *$ significant at $1 \%$. The war regions in Ethiopia are Tigray and Afar. The war regions in Eritrea are Gash Barka, Debub, and Debubawi Keyih Bahri. Data source: 2002 Eritrea and 2000 and 2005 Ethiopia Demographic and Health Surveys. 
Appendix Table 6: Impacts of War Exposure on Child Mortality, Using GPS Location

\begin{tabular}{|c|c|c|}
\hline \multirow[t]{2}{*}{ Dependent Variable: Child Mortality } & \multicolumn{2}{|c|}{ Based on residence at the time of the survey } \\
\hline & $\begin{array}{c}\text { Ethiopia } \\
(1)\end{array}$ & $\begin{array}{l}\text { Eritrea } \\
(2)\end{array}$ \\
\hline Total Months of War Exposure (by Relative Proximity) & $\begin{array}{c}0.0000 \\
{[0.0000]}\end{array}$ & $\begin{array}{c}0.0000 \\
{[0.0000]}\end{array}$ \\
\hline Observations & 16,234 & 5,600 \\
\hline \multicolumn{3}{|c|}{$\begin{array}{l}\text { Notes: Robust standard errors in brackets, clustered at the enumeration level. * significant at } 10 \% \text {, ** } \\
\text { significant at } 5 \% \text {, and *** significant at } 1 \% \text {. All specifications include child age fixed effects, region fixed } \\
\text { effects, region-specific time trends, DHS round fixed effects (for Ethiopia), child gender, and controls for } \\
\text { household characteristics (noted in the text). The child's place of residence is based on the region of } \\
\text { residence at the time of the survey. "Total months of war exposure” measures the number of months a } \\
\text { child was alive or in utero during the war period by proximity to conflict sites. Data source: } 2002 \text { Eritrea } \\
\text { and } 2000 \text { and } 2005 \text { Ethiopia Demographic and Health Surveys. }\end{array}$} \\
\hline
\end{tabular}

